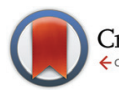

CrossMark \&lick for updates

Cite this: Dalton Trans., 2015, 44, 3686

Received 22nd September 2014, Accepted 17th October 2014

DOI: $10.1039 / \mathrm{c} 4 \mathrm{dt} 02910 \mathrm{k}$

www.rsc.org/dalton

\section{Syntheses of polypyridyl metal complexes and studies of their interaction with quadruplex DNA $\uparrow$}

\author{
Verity S. Stafford, ${ }^{a}$ Kogularamanan Suntharalingam, $\$^{\mathrm{a}}$ Arun Shivalingam, ${ }^{\mathrm{a}}$ \\ Andrew J. P. White, ${ }^{a}$ David J. Mann ${ }^{\mathrm{b}}$ and Ramon Vilar*a
}

\begin{abstract}
A series of mono- and bi-metallic metal complexes (with $\mathrm{Cu}^{\prime \prime}, \mathrm{Pt}^{\prime \prime}$ and $\mathrm{Zn}^{\text {"I }}$ ) with substituted polypyridyl ligands have been prepared and their binding affinities towards quadruplex (c-Myc and human telomeric) and duplex DNA (ds26 and calf thymus) determined using fluorescent indicator displacement (FID) assays and UV/vis spectroscopic titrations. These studies have shown that the number of aromatic rings and number/position of cyclic amine substituents on the ligands, play an important role in defining the DNA binding abilities of the resulting metal complexes. We also show that bi-metallic complexes prepared using a novel terpyridine-cyclen ligand have higher affinity towards G-quadruplex DNA as compared to their mono-metallic counterparts. Cytotoxicity assays were carried out for all the new complexes against an osteosarcoma cancer cell line (U2OS) as well as a normal fibroblast cell line (GM05757). Several of these compounds displayed cytotoxicity similar to that of cisplatin.
\end{abstract}

\section{Introduction}

Guanine-rich oligonucleotides have the ability to self-assemble into quadruply-stranded structures known as G-quadruplexes. ${ }^{1}$ As has been extensively discussed in the recent literature, the formation of G-quadruplex DNA in vivo has been associated with a number of important biological processes including regulation of gene expression and telomere maintenance. ${ }^{2,3}$ Due to their proposed biological relevance, G-quadruplexes are attractive targets for anticancer drugs. ${ }^{4-7}$ Therefore, there has been increasing interest in the development of small molecules able to interact with high affinity and selectivity with quadruplexes. While initially most quadruplex binders were based on purely organic planar molecules, ${ }^{8-10}$ more recently an increasing number of metal complexes have been shown to be excellent quadruplex binders. ${ }^{11}$

Over the past ten years we have developed several families of platinum(II) square planar complexes aimed at interacting with quadruplex DNA structures. The design of these platinum (II) complexes is based around planar polyaromatic ligand frameworks such as salphen, ${ }^{12}$ phenanthroline, ${ }^{13,14}$ disubsti-

\footnotetext{
${ }^{a}$ Department of Chemistry, Imperial College London, London SW7 2AZ, UK. E-mail: r.vilar@imperial.ac.uk

${ }^{b}$ Department of Life Sciences, Imperial College London, London SW7 2AZ, UK $\dagger$ Electronic supplementary information (ESI) available. CCDC 1023715-1023717. For ESI and crystallographic data in CIF or other electronic format see DOI: $10.1039 / \mathrm{c} 4 \mathrm{dt} 02910 \mathrm{k}$

\$Current address: Department of Chemistry, King’s College London, Britannia House, London SE1 IDB, UK.
}

tuted pyridines ${ }^{15}$ and terpyridines. ${ }^{16-18}$ In these examples, the metal plays an important structural role organising the polyaromatic ligands in an optimal planar geometry for end-stacking on top of guanine tetrads (via $\pi-\pi$ interactions). In addition to their structural features, the metal ions withdraw electron density from the corresponding ligand framework which in turn renders the aromatic rings more prone to displaying $\pi-\pi$ stacking interactions. ${ }^{11}$ Another important design feature when developing quadruplex binders is the addition of basic substituents to the planar $\pi-\pi$ stacking core, which can be protonated at physiological $\mathrm{pH}$. These groups have been shown to increase the solubility of the compounds in aqueous media as well as enhancing their interactions with quadruplexes. While most substituents used so far are based on organic groups (e.g. amines, amino acids) we recently incorporated as part of our design a "side-arm" based on a metal complex. ${ }^{16}$ The resulting di-metal complexes displayed higher affinities towards quadruplex DNA in comparison to the corresponding mono-metallic complexes.

The first studies of metal-terpyridines as G-quadruplex binders were reported by Teulade-Fichou et al. ${ }^{19-21}$ These studies showed that square planar and square-based pyramidal metal complexes containing substituted terpyridines, are very good G-quadruplex binders. Subsequently, we synthesised a different family of terpyridine metal complexes (1-4, see Fig. 1) and also showed that the platinum(II) square planar complexes had good affinity for G-quadruplexes. ${ }^{17}$ Ligands based on phenanthroline have also been previously used to prepare metal complexes with high affinity towards quadruplexes. ${ }^{13-15,22-29}$ 
<smiles></smiles><smiles></smiles>

$$
M=Z n \quad 1
$$

$\mathrm{Cu} 2$

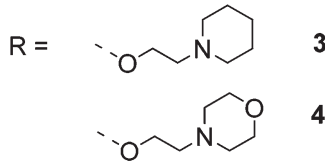

Fig. 1 Metal-terpyridine complexes with $\mathrm{M}=\mathrm{Zn}^{\prime \prime}, \mathrm{Cu}^{\prime \prime}$ and $\mathrm{Pt}$ " previously reported and studied as G-quadruplexe binders.

We have now extended our studies on polypyridyl metal complexes and present our results herein. More specifically, we have synthesised two new ligands $\left(\mathbf{L}^{\mathbf{4}}\right.$ and $\left.\mathbf{L}^{\mathbf{8}}\right)$ and ten new mono- and bi-metallic metal complexes (5-15). The affinity of the new complexes towards G-quadruplex ( $c-M y c$ and HTelo) and duplex (d26 and calf thymus) DNA has been determined by fluorescent indicator displacement (FID) ${ }^{30,31}$ assays and UV/vis spectroscopic titrations. In addition, we report the cytotoxicity of these complexes against the osteosarcoma cancer cell line U2OS as well as against the normal fibroblast cell line GM05757.

\section{Results and discussion}

\section{Synthesis of substituted polypyridyl ligands}

The ligands and complexes studied in this work are shown in Schemes 1 and 2 and Fig. 2-4. The rationale behind these ligands and the corresponding complexes was to explore the effect of various parameters on G-quadruplex binding. In particular, we focussed upon the effects of increasing the number of aromatic rings (e.g. comparing 15 with 3 and 4) and exchan- ging the labile chloride coordinated to the platinum(II) metal centre with a thiolate (complexes 5-7 and 14); we were also interested in studying the impact of a second metal centre within the same molecule (e.g. 11 and 12) on the affinity of the complexes toward G-quadruplex DNA.

Ligands $\mathbf{L}^{2}$ and $\mathbf{L}^{3}$ were prepared as previously reported, ${ }^{17}$ while $\mathbf{L}^{4}$ was prepared by reacting the tri-Boc protected cyclen (Cyc-Tri-BOC), ${ }^{32}$ with 2,6-bis(2-pyridyl) $4(1 H)$ pyridone (see Scheme 1) to first yield $\mathbf{L}^{\mathbf{4}}$-BOC. This intermediate product was treated with TFA in $\mathrm{CH}_{2} \mathrm{Cl}_{2}$ to remove the BOC protecting groups. To neutralise the protonated crude solid, it was first dissolved in water and aqueous $\mathrm{NaOH}$ (2 M) was added dropwise until the solution became alkaline $(\mathrm{pH} 12)$. The product was then extracted into $\mathrm{CH}_{2} \mathrm{Cl}_{2}$. The solvent was removed under reduced pressure to yield $\mathbf{L}^{\mathbf{4}}$ as a pale yellow sticky solid. This terpyridine-cyclen ligand was fully characterised by ${ }^{1} \mathrm{H}$ and ${ }^{13} \mathrm{C}$ NMR spectroscopy (including ${ }^{1} \mathrm{H}-{ }^{1} \mathrm{H}$ COSY NMR - see Fig. S1 in the ESI $\dagger)$, as well as by mass spectrometry $(\mathrm{m} / \mathrm{z}=$ 462 a.m.u., $\left.[\mathrm{M}+\mathrm{H}]^{+}\right)$.

Ligand $\mathbf{L}^{6}$ was prepared by coupling phenanthroline and 2-bromopyridine as shown in Scheme 2. The compound was fully characterized by ${ }^{1} \mathrm{H}$ NMR spectroscopy as well as by mass spectrometry $\left(\mathrm{m} / \mathrm{z}=253\right.$ a.m.u., $\left.[\mathrm{M}+\mathrm{H}]^{+}\right)$and its purity confirmed by elemental analyses. The mono-functionalized pyridyl-phenanthroline ligand, $\mathbf{L}^{\mathbf{8}}$, was prepared using a twostep approach: 5-chloro-1,10-phenanthroline was reacted with 1-(2-hydroxyethyl)piperidine and $\mathrm{KOH}$ in degassed DMSO to yield $\mathbf{L}^{7}$ (Scheme 2). The substituted phenanthroline was then coupled with 2-bromopyridine using ${ }^{n} \mathrm{BuLi}$ as a base. Upon extraction into $\mathrm{CH}_{2} \mathrm{Cl}_{2}$, re-oxidation using $\mathrm{MnO}_{4}$ and purification via alumina column chromatography, the desired product was isolated. The ligand was characterised by ${ }^{1} \mathrm{H}$ NMR spectroscopy where the resonances of the aromatic protons were observed to shift downfield relative to the starting material. Furthermore, formation of the desired $\mathrm{C}-\mathrm{C}$ bond was clearly shown by the disappearance of one ortho-phenanthroline proton signal. A distinctive molecular ion peak was observed in the ESI mass spectrum $(\mathrm{m} / \mathrm{z}=407$ a.m.u., $[\mathrm{M}+\mathrm{Na}]^{+}$), providing further evidence for product formation.

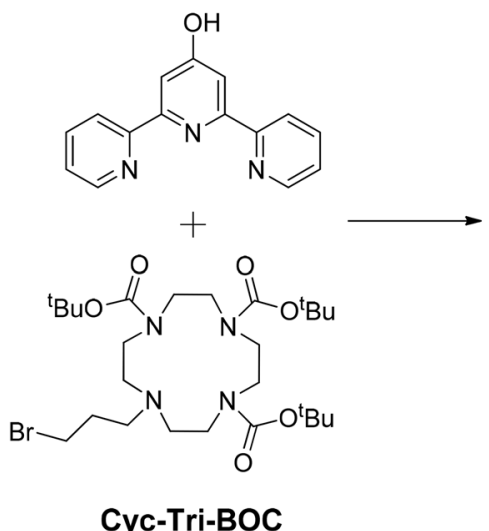

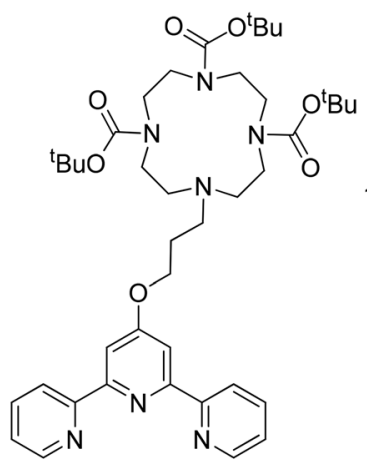

$L^{4}-B O C$

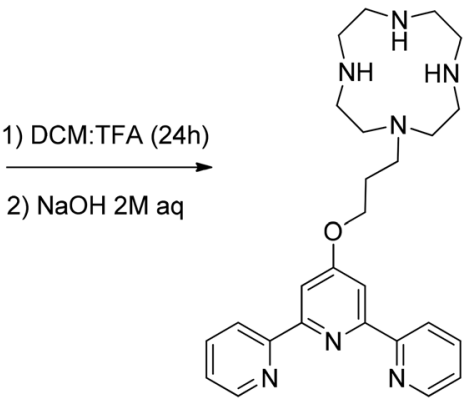

$L^{4}$

Scheme 1 Reaction scheme for the syntheses of ligand $L^{4}$. 
<smiles>c1ccc(-c2cccc(-c3ccccn3)n2)nc1</smiles>

$\mathbf{L}^{1}$

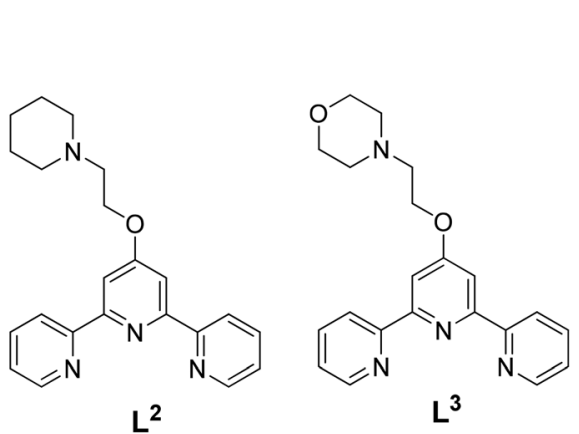<smiles>c1ccc(-c2cc(OCCCN3CCNCCNCCNCC3)cc(-c3ccccn3)n2)nc1</smiles><smiles>SCCN1CCCCC1</smiles>

$\mathbf{L}^{5}$

Fig. 2 Chemical structures of the terpyridine ligands employed to prepare the corresponding metal complexes under investigation.
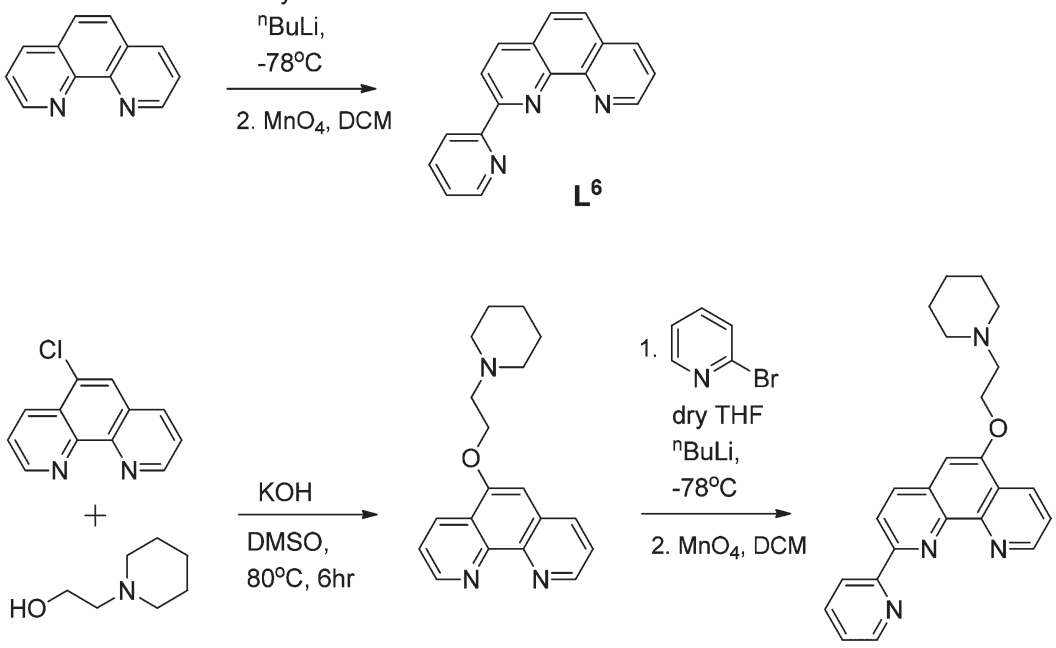

$L^{7}$

$L^{8}$

Scheme 2 Reaction schemes for the syntheses of ligand $L^{6}-L^{8}$.<smiles></smiles><smiles>[R]C1=CC2=C3C=CC=CN3P3N2C(=C1)C(SCCN1CCCCC1)N1C=CC=CN13</smiles>

$R=$

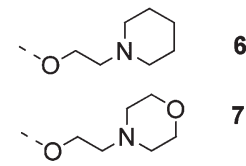

Fig. 3 Chemical structures of the platinum(II)-thiolate complexes 5-7. The counterion for complex 5 is $\mathrm{Cl}^{-}$, while for 6 and 7 is $\mathrm{PF}_{6}^{-}$.

\section{Synthesis of metal complexes}

The new thiolato platinum complexes 5-7 were prepared by reacting the corresponding platinum(II)-terpyridine-chloro derivatives, $\left[\mathrm{Pt}(\right.$ terpy) $\mathrm{Cl}] \mathrm{Cl}, 3$ and $\mathbf{4}$, with 4 equivalents of $\mathbf{L}^{\mathbf{5}}$ (which was prepared by modification of a reported procedure $^{33}$ ) in water at $25{ }^{\circ} \mathrm{C}$ for $48 \mathrm{~h}$. Upon completion of the reactions, excess thiol starting material was removed. Complex 5 (as the chloride salt $\left[\operatorname{Pt}\left(\mathbf{L}^{\mathbf{1}}\right)\left(\mathbf{L}^{\mathbf{5}}\right)\right] \mathrm{Cl}$ ) was isolated as a deep purple solid. In contrast, complexes 6 and 7 could not be isolated pure as the chloride salts. In these cases an additional counter-anion exchange step was required, so the chloride ion was exchanged for $\mathrm{PF}_{6}{ }^{-}$ion to yield $\left[\mathrm{Pt}\left(\mathbf{L}^{3}\right)\left(\mathbf{L}^{5}\right)\right]\left(\mathrm{PF}_{6}\right)(\mathbf{6})$ and $\left[\mathrm{Pt}\left(\mathbf{L}^{\mathbf{4}}\right)\left(\mathbf{L}^{5}\right)\right]\left(\mathrm{PF}_{6}\right)(7)$ as orange solids.

The platinum(II)-thiol complexes were fully characterised by ${ }^{1} \mathrm{H}$ NMR (and ${ }^{31} \mathrm{P}$ NMR in the case of 6 and 7) spectroscopy, UV-Vis spectroscopy, mass spectrometry and elemental analyses. The aromatic proton signals were observed to shift 


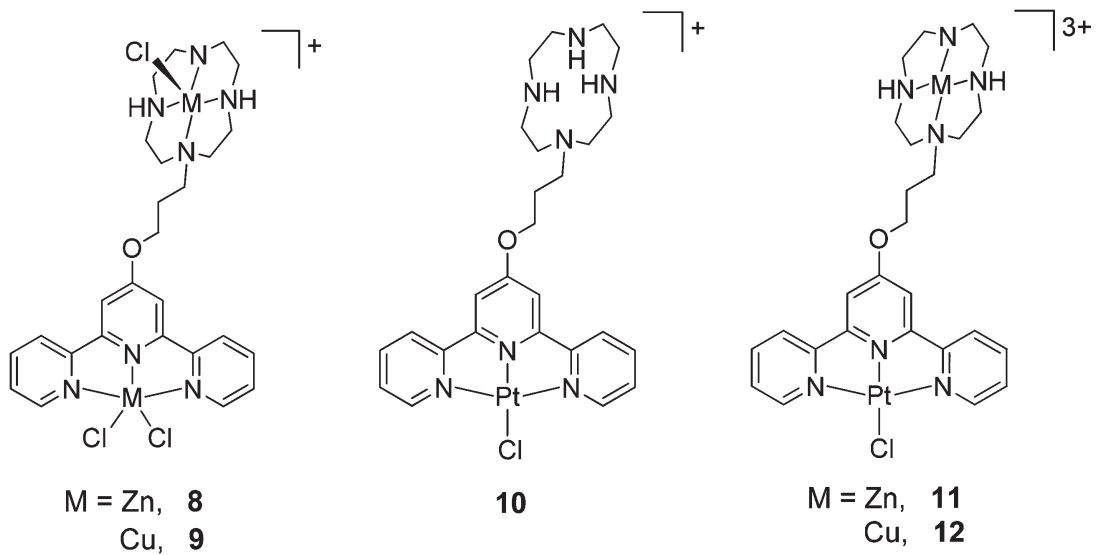

Fig. 4 Chemical structures of the zinc(II), copper(II) and platinum(II)-terpy-cyclen mono- and di-metallic complexes 8-12. The counterion for complex 8 is $1 / 2\left[\mathrm{ZnCl}_{4}\right]^{2-}$, for 9 is $\mathrm{Cl}^{-}$and for $10-12 \mathrm{PF}_{6}^{-}$.

downfield (ranging from 0.2 to $0.8 \mathrm{ppm}$ ) relative to the corresponding platinum(II)-chloro complexes, clearly demonstrating coordination of the thiol arm to the fourth position of the platinum(II)-terpyridine motif. The largest shift was observed for the ortho-terpyridine peak ( $0.8 \mathrm{ppm}$ downfield), likely to result from the magnetic anisotropy of the neighbouring platinum-sulfur bond. The appearance of a LMCT/ILCT band (charge transfer from the sulfur $\mathrm{p}$ orbital to the platinum/ terpyridine orbitals) at $505 \mathrm{~nm}$ in the UV-vis spectrum provided further evidence for the successful coordination of the thiol ligand. Complex $\mathbf{5}$ was also characterised by X-ray crystallography (see below).

The dinuclear complexes $\mathbf{8}$ and $\mathbf{9}$ were prepared by reacting $\mathbf{L}^{4}$ (in methanol) with a methanolic solution containing 2 equivalents of the appropriate metal chloride salt $\left(\mathrm{ZnCl}_{2}\right.$ and $\mathrm{CuCl}_{2} \cdot 2 \mathrm{H}_{2} \mathrm{O}$ respectively). These solutions were heated at $40{ }^{\circ} \mathrm{C}$ for $48 \mathrm{~h}$ after which time white and blue precipitates were obtained for the zinc(II) (8) and copper(II) (9) complexes respectively. These solids were purified by recrystallization: acetone was allowed to slowly diffuse into concentrated aqueous solutions of the complexes over 7 days yielding crystals of $\mathbf{8}$ and $\mathbf{9}$ suitable for X-ray crystallographic analysis (see below). These crystalline solids were also characterised by mass spectrometry and elemental analyses. The di-zinc(II) complex 8 was further characterised by ${ }^{1} \mathrm{H}$ and ${ }^{13} \mathrm{C}$ NMR spectroscopy (including ${ }^{1} \mathrm{H}-{ }^{1} \mathrm{H}$ COSY NMR - see Fig. S2 in the ESI†).

Complex 10 was prepared by reacting $\mathbf{L}^{4}$ with $\mathrm{K}_{2} \mathrm{PtCl}_{4}$ in DMSO for $24 \mathrm{~h}$. Addition of acetone to the reaction mixture yielded an orange solid (the chloride salt of 10) which was subsequently redissolved in DMSO and treated with an aqueous solution of $\mathrm{NaPF}_{6}$ to precipitate $\mathbf{1 0}$ as the pure $\mathrm{PF}_{6}{ }^{-}$salt. This complex was characterised by ${ }^{1} \mathrm{H}$ and ${ }^{13} \mathrm{C}$ NMR spectroscopy, mass spectrometry and elemental analyses. The hetero-bimetallic complexes $\mathbf{1 1}$ and $\mathbf{1 2}$ were prepared by reacting $\mathbf{1 0}$ with the corresponding metal salt $\left(\mathrm{ZnCl}_{2}\right.$ and $\mathrm{CuCl}_{2} \cdot 2 \mathrm{H}_{2} \mathrm{O}$ respectively) in DMSO. Addition of aqueous $\mathrm{NaPF}_{6}$ to this solution yielded the corresponding $\mathrm{Pt}-\mathrm{Zn}$ and $\mathrm{Pt}-\mathrm{Cu}$ complexes as yellow and green solids respectively. Both complexes were characterised spectroscopically and by elemental analyses.

The two phenanthroline-based ligands $\mathbf{L}^{6}$ and $\mathbf{L}^{8}$ were reacted with $\left[\mathrm{Pt}(\mathrm{COD}) \mathrm{Cl}_{2}\right]$ in water at $75^{\circ} \mathrm{C}$ for $3 \mathrm{~h}$ to yield the corresponding platinum(II) complexes $\mathbf{1 3}$ and $\mathbf{1 5}$ (isolated as the $\mathrm{Cl}^{-}$and $\mathrm{PF}_{6}{ }^{-}$salts respectively). Complex 13 (which has been previously reported ${ }^{34}$ ) was then reacted with thiol $\mathbf{L}^{5}$ in water to yield the new complex 14 (Fig. 5). These three platinum complexes were fully characterised by ${ }^{1} \mathrm{H}$ NMR spectroscopy, mass spectrometry and elemental analyses.
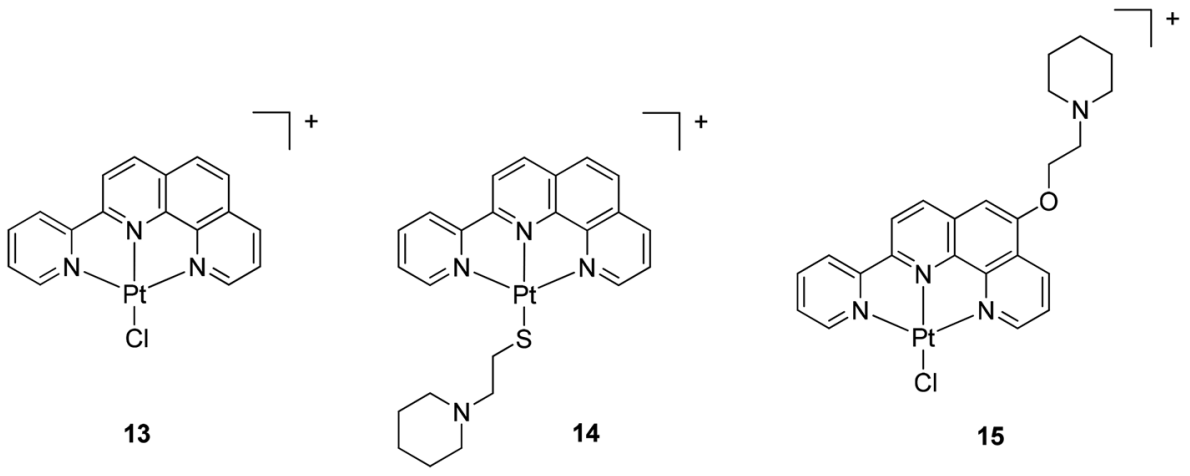

Fig. 5 Chemical structures of the platinum(॥)-phenanthroline complexes $13-15$. The counterion for complex 13 is $\mathrm{Cl}^{-}$, while for 14 and 15 is $\mathrm{PF}_{6}^{-}$. 


\section{X-ray crystal structures of compounds 5, 8 and 9}

Crystals of 5 suitable for an X-ray crystallographic study were grown by slow diffusion of diethyl ether into a methanolic solution of the compound. The platinum centre in the structure of this complex (Fig. 6) was found to have adopted a distorted square planar coordination geometry, the $\mathrm{Pt}, \mathrm{N}(1), \mathrm{N}(8)$, $\mathrm{N}(14)$ and $\mathrm{S}(19)$ atoms being coplanar to within ca. $0.01 \AA$. This planarity extends to include the terpyridine unit, the twenty non-hydrogen atoms being coplanar to within ca. $0.08 \AA$ A. This extended planarity allows the cations in $\mathbf{5}$ to pack across two independent centres of symmetry to form an extended stack along the crystallographic a axis direction (Fig. 7). The N(1)-based ring in one cation links to its counterpart in an adjacent $C_{i}$-related cation (centroid...centroid and mean interplanar separations of $c a .3 .68$ and $3.41 \AA$, rings parallel, interaction a in Fig. 7), whilst the N(8)- and N(14)-based rings are linked across an independent centre of symmetry (centroid...centroid and mean interplanar separations of ca. 3.81 and $3.40 \AA$, rings inclined by $c a .4^{\circ}$, interaction b in Fig. 7).

The structure of the di-zinc complex 8 (crystals of which were grown by slow diffusion of acetone into concentrated aqueous solution of the complex) was found to contain two independent cations (8-A and 8-B) with noticeably different coordination geometries between the terpyridine unit and the $\mathrm{ZnCl}_{2}$ moiety (cation 8-A is shown in Fig. 8, whilst cation 8-B is shown in Fig. S6 in the ESI†). For cation 8-B the terpyridine unit is approximately planar, and this plane includes the metal atom with $\mathrm{Zn}(1 \mathrm{~B})$ lying only $c a$. $0.02 \AA$ out of the $\mathrm{N}_{3}$ plane (the torsion angles between the N(1B)- and $\mathrm{N}(8 \mathrm{~B})$-based rings, and between the $\mathrm{N}(1 \mathrm{~B})$ - and $\mathrm{N}(14 \mathrm{~B})$-based rings being ca. 3 and $1^{\circ}$ respectively). This results in a distorted trigonal bipyramidal coordination geometry at $\mathrm{Zn}(1 \mathrm{~B})$ with a signifi-

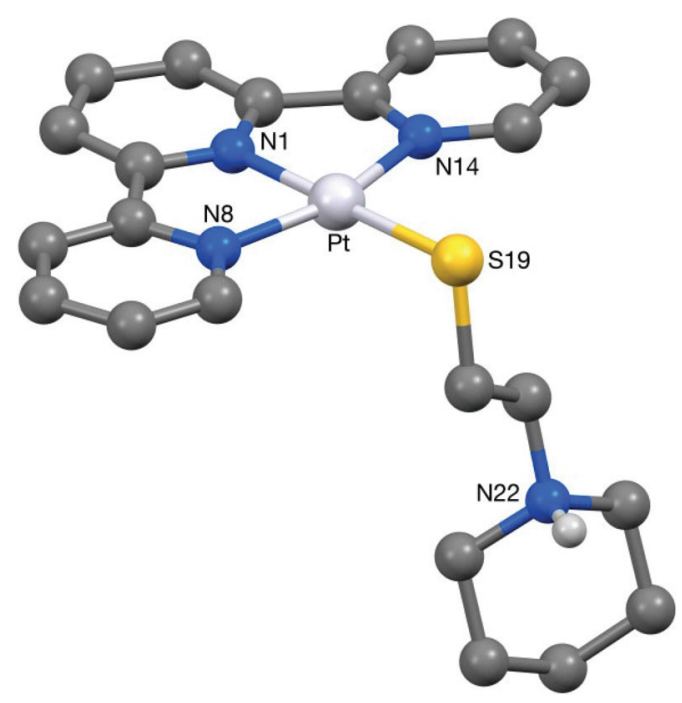

Fig. 6 The structure of the di-cationic complex present in the crystal of 5. Selected bond lengths $(\AA)$ and angles $\left({ }^{\circ}\right)$; Pt-N(1) 1.972(3), Pt-N(8) 2.026(4), Pt-N(14) 2.044(4), Pt-S(19) 2.3131(10), N(1)-Pt-N(8) 80.69(14), $\mathrm{N}(1)-\mathrm{Pt}-\mathrm{N}(14) \quad 80.60(15), \quad \mathrm{N}(1)-\mathrm{Pt}-\mathrm{S}(19) \quad 178.78(10), \quad \mathrm{N}(8)-\mathrm{Pt}-\mathrm{N}(14)$ 161.29(15), N(8)-Pt-S(19) 98.57(11), N(14)-Pt-S(19) 100.13(11).

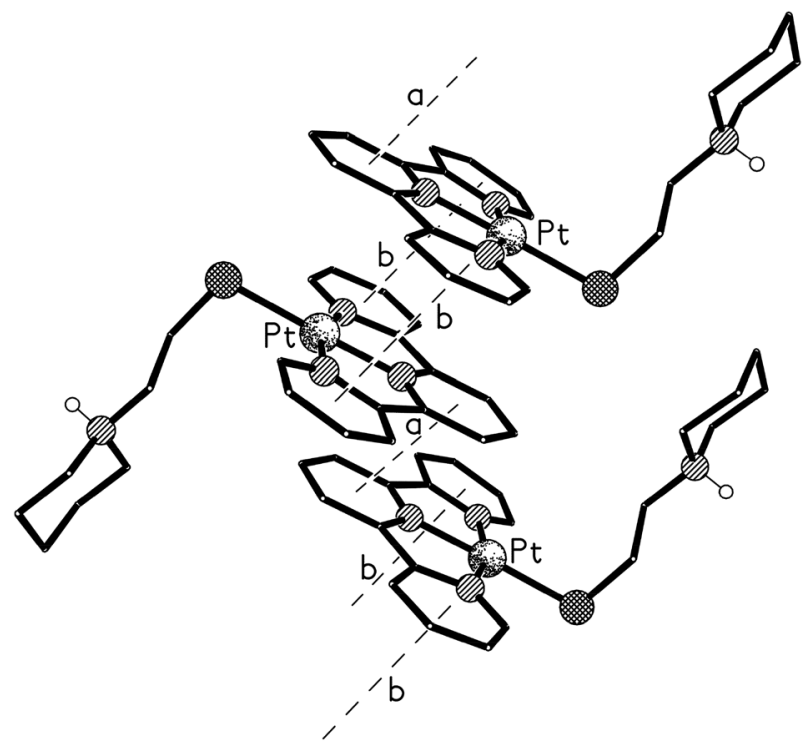

Fig. 7 Part of one of the $\pi-\pi$ linked stacks of cations along the a-axis direction present in the crystal of 5 . The $\pi-\pi$ stacking interactions have centroid …centroid and mean interplanar separations ( $\AA$ ) of (a) $3.69,3.35$, and (b) $3.80,3.40$ respectively.

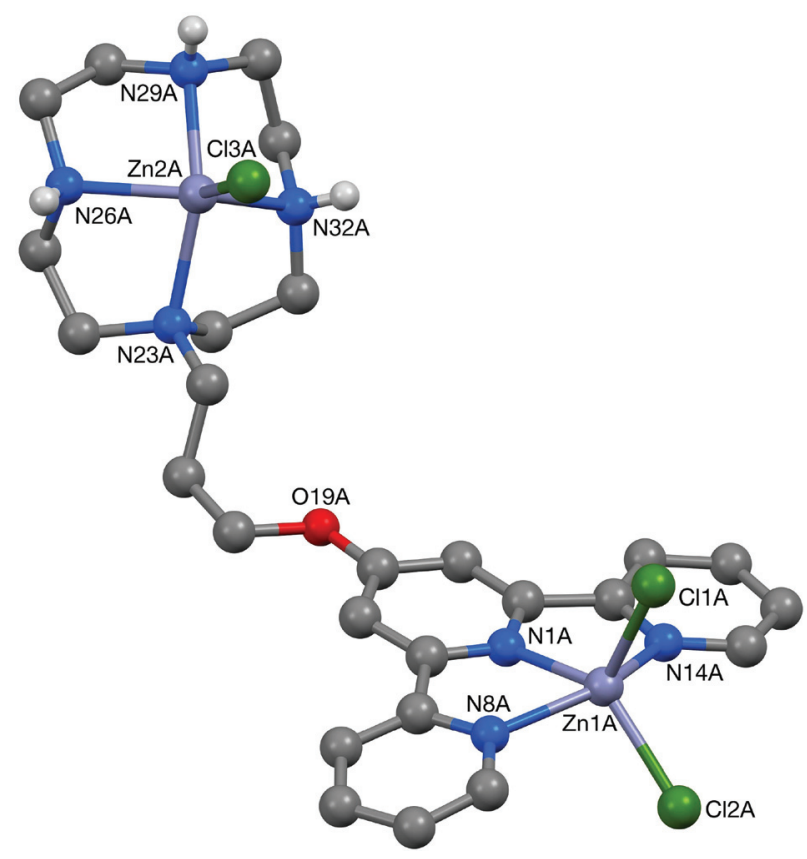

Fig. 8 The structure of one (8-A) of the two independent cationic complexes present in the crystal of 8 .

cantly bent major axis $\left[\mathrm{N}(8 \mathrm{~B})-\mathrm{Zn}(1 \mathrm{~B})-\mathrm{N}(14 \mathrm{~B}) \quad 150.33(9)^{\circ}\right.$, Table 1]. Cation 8-A has a noticeably different geometry at $\mathrm{Zn}(1 \mathrm{~A})$ with the metal slightly perching above the $\mathrm{N}_{3}$ plane by ca. $0.32 \AA$. This perching distorts the terpyridine unit away from planarity, the torsion angles between the $\mathrm{N}(1 \mathrm{~A})$ - and $\mathrm{N}(8 \mathrm{~A})$-based rings, and between the $\mathrm{N}(1 \mathrm{~A})$ - and $\mathrm{N}(14 \mathrm{~A})$-based rings being $\mathrm{ca} .13$ and $2^{\circ}$ respectively, resulting in a coordination geometry best described as distorted square-based 
Table 1 Selected bond lengths $(\AA \AA)$ and angles $\left({ }^{\circ}\right)$ for 8-A, 8-B and 9

\begin{tabular}{llll}
\hline & 8-A $[\mathrm{M}=\mathrm{Zn}]$ & $\mathbf{8 - B}[\mathrm{M}=\mathrm{Zn}]$ & $\mathbf{9}[\mathrm{M}=\mathrm{Cu}]$ \\
\hline $\mathrm{M}(1)-\mathrm{Cl}(1)$ & $2.2614(8)$ & $2.2678(8)$ & $2.5361(17)$ \\
$\mathrm{M}(1)-\mathrm{Cl}(2)$ & $2.2903(7)$ & $2.2680(7)$ & $2.2341(18)$ \\
$\mathrm{M}(1)-\mathrm{N}(1)$ & $2.094(2)$ & $2.077(2)$ & $1.944(5)$ \\
$\mathrm{M}(1)-\mathrm{N}(8)$ & $2.183(2)$ & $2.175(3)$ & $2.051(4)$ \\
$\mathrm{M}(1)-\mathrm{N}(14)$ & $2.193(2)$ & $2.205(2)$ & $2.030(6)$ \\
$\mathrm{Cl}(1)-\mathrm{M}(1)-\mathrm{Cl}(2)$ & $109.38(3)$ & $113.46(3)$ & $101.61(7)$ \\
$\mathrm{Cl}(1)-\mathrm{M}(1)-\mathrm{N}(1)$ & $114.19(6)$ & $116.47(7)$ & $102.66(12)$ \\
$\mathrm{Cl}(1)-\mathrm{M}(1)-\mathrm{N}(8)$ & $106.41(7)$ & $96.22(7)$ & $94.06(12)$ \\
$\mathrm{Cl}(1)-\mathrm{M}(1)-\mathrm{N}(14)$ & $97.47(6)$ & $97.65(6)$ & $96.10(15)$ \\
$\mathrm{Cl}(2)-\mathrm{M}(1)-\mathrm{N}(1)$ & $136.40(6)$ & $130.07(7)$ & $155.73(13)$ \\
$\mathrm{Cl}(2)-\mathrm{M}(1)-\mathrm{N}(8)$ & $94.80(6)$ & $99.28(7)$ & $98.34(14)$ \\
$\mathrm{Cl}(2)-\mathrm{M}(1)-\mathrm{N}(14)$ & $98.85(6)$ & $99.02(6)$ & $98.4(2)$ \\
$\mathrm{N}(1)-\mathrm{M}(1)-\mathrm{N}(8)$ & $74.91(8)$ & $75.24(9)$ & $79.71(17)$ \\
$\mathrm{N}(1)-\mathrm{M}(1)-\mathrm{N}(14)$ & $74.25(8)$ & $75.10(8)$ & $79.3(2)$ \\
$\mathrm{N}(8)-\mathrm{M}(1)-\mathrm{N}(14)$ & $146.69(9)$ & $150.33(9)$ & $158.3(2)$ \\
& & &
\end{tabular}

pyramidal with $\mathrm{Cl}(1 \mathrm{~A})$ in the apical position (the four atoms of the basal plane are coplanar to $c a .0 .23 \AA$ with the metal lying ca. $0.63 \AA$ out of this plane). By contrast the coordination geometries at the $\mathrm{Zn}(2)$ centres are very similar in both independent cations, each having a square-based pyramidal geometry with $\mathrm{Cl}(3)$ in the apical site; the four coordinated nitrogen centres are coplanar to within $c a .0 .03$ and $0.02 \AA$ in 8-A and 8B respectively, with $\mathrm{Zn}(2)$ lying $c a .0 .83 \AA$ (8-A) and $0.80 \AA$ (8-B) out of this plane.

The two independent cations are both arranged in $\pi-\pi$ linked dimer pairs across a centre of symmetry, with in each case the $\mathrm{N}(1)$-based pyridyl ring in one cation overlaying the $\mathrm{N}(14)$-based ring in the $C_{i}$-related counterpart, and vice versa (for cation 8-A: centroid...centroid and mean interplanar separations of $c a .3 .72$ and $3.33 \AA$, rings inclined by $c a .3^{\circ}$, interaction a in Fig. 9, and for cation 8-B: centroid $\cdots$ centroid and mean interplanar separations of $c a .3 .56$ and $3.42 \AA$, rings inclined by less than $1^{\circ}$, interaction $\mathbf{b}$ in Fig. 9). These dimer pairs are then joined by a further $\pi-\pi$ interaction across an independent centre of symmetry between the "unused" pyridyl rings based on $\mathrm{N}(8)$ (centroid ...centroid and mean interplanar separations of $c a .3 .65$ and $3.39 \AA$, rings inclined by $c a .13^{\circ}$, interaction $\mathbf{c}$ in Fig. 9) forming the extended $\cdots \mathrm{AA} \cdots \mathrm{B}-$ B $\cdots A A \cdots B B \cdots$ chain shown in Fig. 9.

Crystals of the di-copper complex 9 were obtained from slow diffusion of acetone into concentrated aqueous solution of the complex. The cation in the structure of this di-nuclear complex (Fig. 10, Table 1) has an approximately planar terpyridine unit with the $\mathrm{Cu}(1)$ centre lying $c a .0 .13 \AA$ out of the $\mathrm{N}_{3}$ plane (the torsion angles between the $\mathrm{N}(1)$ - and $\mathrm{N}(8)$-based rings, and between the $\mathrm{N}(1)$ - and $\mathrm{N}(14)$-based rings being less than $1^{\circ}$ and $c a .3^{\circ}$ respectively). The coordination geometry at the $\mathrm{Cu}(1)$ atom is distorted square based pyramidal with $\mathrm{Cl}(1)$ in the apical position. (The four atoms of the basal plane are coplanar to $c a$. $0.15 \AA$ with the metal lying $c a$. $0.31 \AA$ out of this plane.) The coordination geometry at $\mathrm{Cu}(2)$ is a much less distorted square-based pyramid with $\mathrm{Cl}(3)$ in the apical site; the four coordinated nitrogen centres are coplanar to within ca. $0.01 \AA$, with $\mathrm{Cu}(2)$ lying $c a$. 0.51 out of this plane..$^{35}$

The cations are arranged in $\pi-\pi$ linked dimer pairs across a centre of symmetry, with the N(1)-based pyridyl ring in one cation overlaying the $\mathrm{N}(8)$-based ring in the $C_{i}$-related counterpart, and vice versa (centroid...centroid and mean interplanar separations of $c a$. 3.67 and $3.36 \AA$, rings inclined by less than $1^{\circ}$, interaction a in Fig. 11). These dimer pairs are then joined across a $C_{2}$-axis by a further $\pi-\pi$ interaction between the "unused" pyridyl rings based on $\mathrm{N}(14)$ (centroid...centroid and mean interplanar separations of $c a .3 .81$ and $3.62 \AA$, rings inclined by less than $1^{\circ}$, interaction $\mathbf{b}$ in Fig. 11) forming an

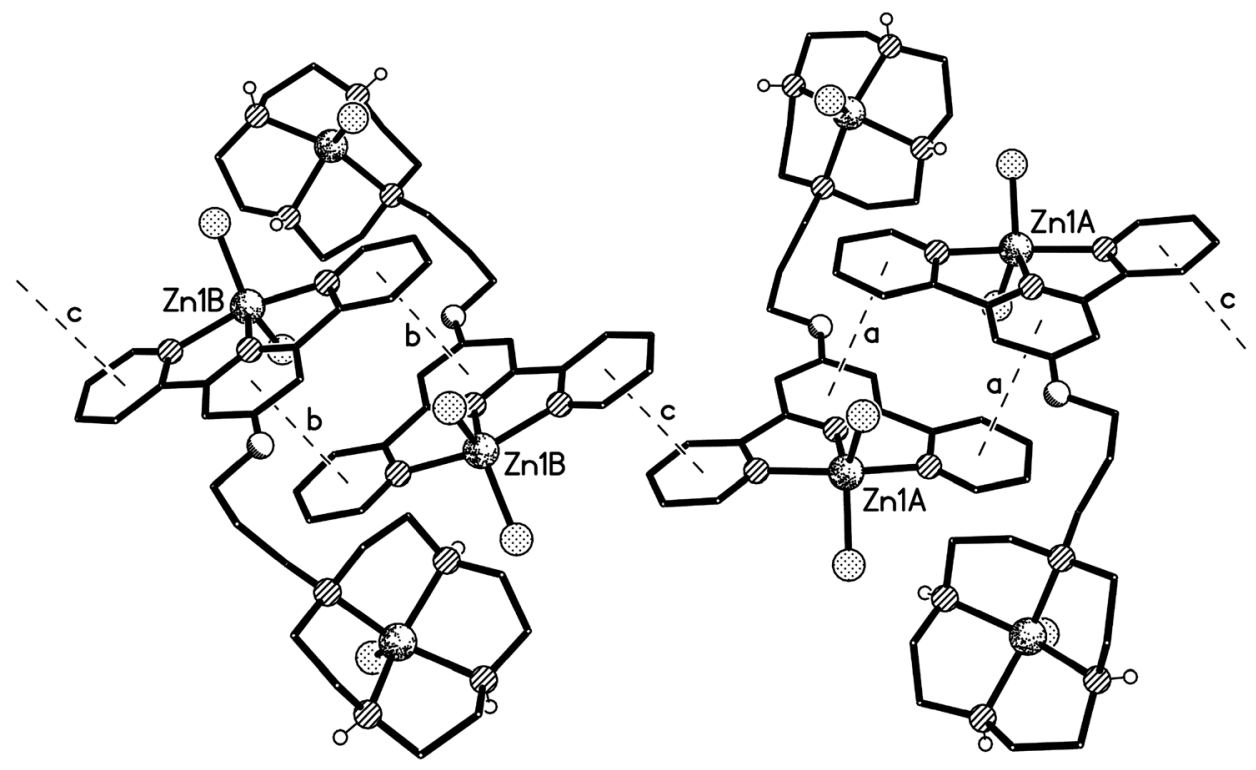

Fig. 9 Part of one of the $\pi-\pi$ linked chains of cations present in the crystal of 8 . The $\pi-\pi$ stacking interactions have centroid $\cdots$ centroid and mean interplanar separations ( $\AA$ ) of (a) $3.72,3.33$, (b) $3.56,3.42$ and (c) $3.65,3.39$ respectively. 


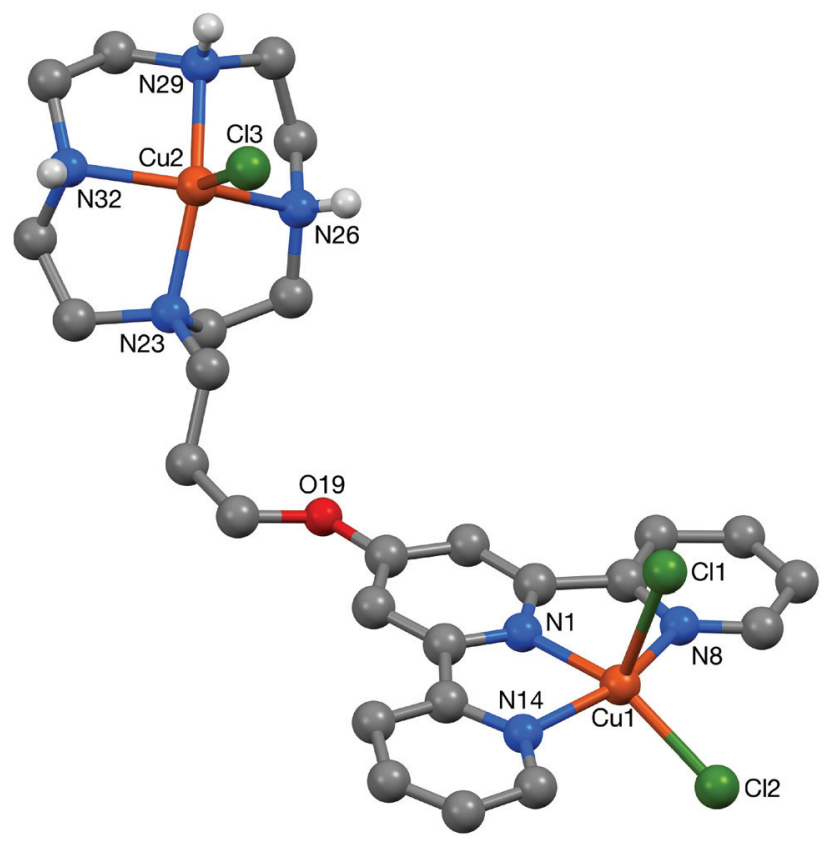

Fig. 10 The structure of the cationic complex present in the crystal of 9.

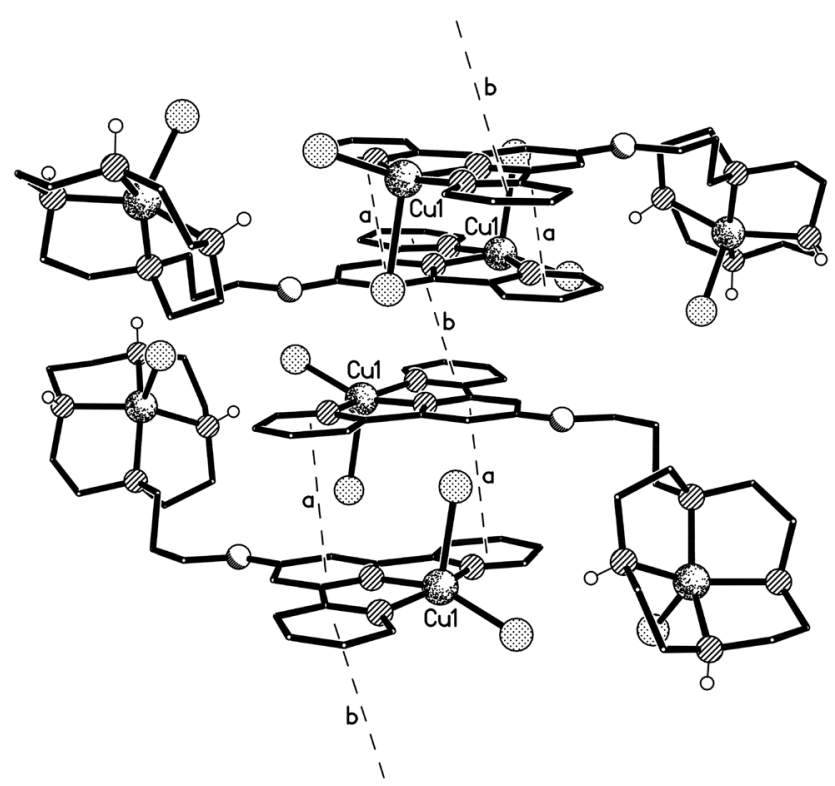

Fig. 11 Part of one of the $\pi-\pi$ linked stacks of cations along the $c$-axis direction present in the crystal of 9 . The $\pi-\pi$ stacking interactions have centroid ‥centroid and mean interplanar separations ( $(\AA)$ of (a) $3.67,3.36$ and (b) $3.81,3.62$ respectively.

extended chain along the crystallographic $c$-axis direction (Fig. 11).

\section{Biophysical studies to determine the interactions between metal complexes and DNA}

We first investigated the affinity of the complexes towards two quadruplexes (human telomeric, Htelo, and $c-M y c$ DNA) and duplex ds26 DNA by fluorescent intercalator displacement (FID) assays. ${ }^{31,36}$ The results presented as $\mathrm{DC}_{50}$ values in Table 2 (i.e. the concentration at which $50 \%$ of thiazole orange (TO) had been displaced) indicates that several of the complexes are excellent quadruplex binders (with $\mathrm{DC}_{50}<0.4 \mu \mathrm{M}$ ) and in some cases considerably selective over duplex ds26 DNA. It can also be observed that most of the complexes display lower $\mathrm{DC}_{50}$ values (i.e. higher affinity) for $c-M y c$ than Htelo DNA.

Since FID assays are semiquantitative and therefore provide only an overview of the binding affinities between small molecules and DNA, a second technique to assess the binding was employed. Thus, UV-Vis spectroscopic studies were carried out with the corresponding complexes and DNA (Htelo, $c-M y c$ and ct-DNA - the latter as an example of duplex DNA), using a previously established protocol. ${ }^{37}$ In order to perform these studies the test compounds were required to have an absorption maximum above $300 \mathrm{~nm}$ (higher than the $\lambda_{\max }$ of DNA, $260 \mathrm{~nm}$ ) and show optical changes when interacting with DNA. As the free ligands did not have absorption bands above $300 \mathrm{~nm}$, only the metal complexes were tested. Due to the poor binding affinity of $\mathbf{1}$ and $\mathbf{2}$ to quadruplex DNA (as determined from the FID assay), these complexes were omitted from the UV-vis titration studies. Upon addition of aliquots of DNA (in the $\mathrm{mM}$ range) to solutions of the corresponding metal complexes, the absorption maximum was seen to decrease. From the absorption values, the concentrations of bound and unbound metal complex were calculated and extrapolated to determine the binding constants. This was done by fitting the data to a reciprocal plot of $D / \Delta \varepsilon_{\text {ap }}$ versus $D$ using the following equation: $D / \Delta \varepsilon_{\text {ap }}=D / \Delta \varepsilon+1 /(\Delta \varepsilon \times K)$ where the concentration of DNA $(D)$ is expressed in terms of base pairs (determined by measuring the absorption at $260 \mathrm{~nm}$ and the appropriate extinction coefficients), the apparent molar extinction coefficient $\varepsilon_{\mathrm{a}}=A_{\text {observed }} /\left[\right.$ Complex], $\Delta \varepsilon_{\mathrm{ap}}=\left[\varepsilon_{\mathrm{a}}-\varepsilon_{\mathrm{f}}\right]$ and $\Delta \varepsilon=\left[\varepsilon_{\mathrm{b}}-\varepsilon_{\mathrm{f}}\right]$. $\varepsilon_{\mathrm{b}}$ is the extinction coefficient of the DNA bound complex, and $\varepsilon_{\mathrm{f}}$ is the extinction coefficient of the free complex. ${ }^{38}$ The intrinsic binding affinities toward the different DNA sequences were determined and are summarised in Table 3. These studies showed that most of the complexes have good affinity towards quadruplex DNA and they have generally higher affinity for $c$-Myc DNA over Htelo DNA and quadruplex DNA over ct-DNA. In particular, complexes 9-12 (with the pyridine-cyclen ligand $\left.\mathbf{L}^{4}\right)$ showed to have very high affinity towards G-quadruplexes particularly $c-M y c$ - and, up to 1000 -fold selectivity over ct-DNA. The rationale for developing these complexes in the first place, was to test whether the addition of a second metal complex to the square planar platinum(II)-terpyridine or the square-based pyramidal copper(II)-terpyridine complexes would yield better quadruplex DNA binders. In particular, we chose the cyclen unit as a second coordinating ligand because: (a) cyclen does not coordinate with high affinity to platinum(II) and therefore it was possible to prepare mixed-metal complexes (11 and 12); (b) zinc(II)-cyclen complexes have been previously reported to have good affinity for phosphates ${ }^{39-42}$ and hence we rationalised that this type of moiety would be able to 
Table $2 \mathrm{DC}_{50}$ values obtained for the metal(I) complexes. The values are an average of three independent measurements (errors were within $5 \%$ ). The $\mathrm{DC}_{50}$ values for $1-4$ have been previously reported. ${ }^{16,17}$

\begin{tabular}{|c|c|c|c|c|c|}
\hline Compound & \multicolumn{3}{|c|}{ TO displacement } & \multicolumn{2}{|l|}{ Selectivity } \\
\hline 2 & 1.32 & 2.45 & 2.16 & 1.6 & - \\
\hline 3 & 1.25 & 0.26 & 2.44 & 2.0 & 9.4 \\
\hline 4 & 2.24 & 1.01 & $>2.50$ & 1.1 & 2.5 \\
\hline 5 & 0.46 & 0.30 & 0.68 & 1.5 & 2.3 \\
\hline 8 & 2.75 & 0.86 & 3.34 & 1.2 & 3.9 \\
\hline 9 & 0.21 & 0.09 & 0.60 & 2.9 & 6.7 \\
\hline 10 & 0.28 & 0.16 & 0.70 & 2.5 & 4.4 \\
\hline 11 & 0.35 & 0.08 & 1.50 & 4.3 & 18.8 \\
\hline 12 & 0.18 & 0.17 & 0.77 & 4.3 & 4.5 \\
\hline 13 & 0.66 & 0.27 & 1.18 & 1.8 & 4.4 \\
\hline 14 & 0.40 & 0.13 & 0.71 & 1.8 & 5.5 \\
\hline
\end{tabular}

Table 3 DNA affinity constants from UV/Vis spectroscopic titrations. Values are an average of 3 independent measurements. The previously reported $K$ values for 3 are included for comparison ${ }^{17}$

\begin{tabular}{llll}
\hline Compound & ${ }^{\mathrm{c}-\mathrm{Myc}} K\left(\mathrm{M}^{-1}\right)$ & ${ }^{\text {Htelo }} K\left(\mathrm{M}^{-1}\right)$ & ${ }^{\mathrm{ct}-\mathrm{DNA}} K\left(\mathrm{M}^{-1}\right)$ \\
\hline $\mathbf{3}$ & $6.33 \pm 0.32 \times 10^{6}$ & $1.83 \pm 0.57 \times 10^{6}$ & $9.24 \pm 0.72 \times 10^{4}$ \\
$\mathbf{4}$ & $1.64 \pm 0.32 \times 10^{7}$ & $1.75 \pm 0.53 \times 10^{6}$ & $2.18 \pm 0.23 \times 10^{5}$ \\
$\mathbf{5}$ & $4.87 \pm 0.44 \times 10^{7}$ & $1.95 \pm 0.29 \times 10^{6}$ & $1.10 \pm 0.23 \times 10^{6}$ \\
$\mathbf{6}$ & $1.32 \pm 0.42 \times 10^{7}$ & $1.06 \pm 0.11 \times 10^{7}$ & $1.95 \pm 0.52 \times 10^{5}$ \\
$\mathbf{7}$ & $6.85 \pm 0.24 \times 10^{7}$ & $1.60 \pm 0.72 \times 10^{7}$ & $5.46 \pm 1.10 \times 10^{5}$ \\
$\mathbf{8}$ & $7.45 \pm 1.05 \times 10^{6}$ & $1.12 \pm 0.45 \times 10^{6}$ & $2.40 \pm 1.56 \times 10^{5}$ \\
$\mathbf{9}$ & $5.57 \pm 3.58 \times 10^{8}$ & $1.46 \pm 0.19 \times 10^{7}$ & $2.80 \pm 0.41 \times 10^{5}$ \\
$\mathbf{1 0}$ & $1.12 \pm 0.55 \times 10^{8}$ & $1.47 \pm 0.93 \times 10^{7}$ & $1.92 \pm 1.39 \times 10^{5}$ \\
$\mathbf{1 1}$ & $2.81 \pm 0.31 \times 10^{8}$ & $1.90 \pm 1.27 \times 10^{7}$ & $4.00 \pm 2.06 \times 10^{5}$ \\
$\mathbf{1 2}$ & $1.41 \pm 0.94 \times 10^{8}$ & $2.35 \pm 0.35 \times 10^{7}$ & $9.43 \pm 1.11 \times 10^{5}$ \\
$\mathbf{1 3}$ & $1.42 \pm 0.10 \times 10^{7}$ & $6.21 \pm 1.56 \times 10^{6}$ & $5.20 \pm 1.32 \times 10^{5}$ \\
$\mathbf{1 4}$ & $1.14 \pm 0.22 \times 10^{7}$ & $1.46 \pm 0.15 \times 10^{6}$ & $1.07 \pm 0.21 \times 10^{6}$ \\
$\mathbf{1 5}$ & $5.52 \pm 0.42 \times 10^{6}$ & $8.00 \pm 1.23 \times 10^{5}$ & $4.35 \pm 1.19 \times 10^{4}$
\end{tabular}

interact with the phosphate backbone of DNA; furthermore, it is well established that zinc(II)-cyclen complexes have high affinity for thymine and therefore one could expect strong interactions with bases in the loops of DNA. ${ }^{43-47}$ Indeed, the results obtained indicate that these bi-metallic complexes are excellent quadruplex DNA binders and the cyclen unit seems to provide them with high affinity over duplex DNA (even for complex 10 where the cyclen is metal-free).

UV-Vis spectroscopic titrations were also used to probe the binding mode between the complexes and the different DNA structures. Red shifts in absorption bands above $300 \mathrm{~nm}$ (those corresponding to MLCT or intraligand $\pi-\pi^{*}$ transitions) are characteristic of $\pi-\pi^{42}$ interaction with DNA bases. ${ }^{4-50}$ This is generally suggestive of intercalative (for duplex DNA) or end-stacking (for quadruplex DNA) binding modes. The addition of Htelo DNA to the mono-platinum(II) terpyridine complexes 3-7, resulted in considerable hypochromicity of the metal perturbed intraligand $\pi-\pi^{*}$ band (ranging from $22-33 \%)$. A noticeable red shift (4-6 nm) was also observed for the complexes. These spectral features are suggestive of an end-stacking binding mode. Interestingly upon addition of c-Myc DNA, reduced hypochromicity (9-15\%) and very small red shifts (1-2 nm) were observed. The latter suggests binding to $c-M y c$ DNA may not necessarily be restricted to end-stacking but could also involve supplementary interactions with the DNA's loops and phosphate backbone. On the other hand, for the mono-platinum(II) phenanthroline-based complexes (13-15), addition of DNA (quadruplex and duplex) resulted in large hypochromicity (ranging from 18-38\%) but no red shift. This suggests that for these complexes binding may not exclusively result from $\pi-\pi$ stacking interactions. For complexes 9-12, significant hypochromicity was seen upon addition of Htelo, $c-M y c$ and ct-DNA (9-25\%) but no significant bathochromicity (red shift) was observed. This again suggests that the binding mode of these complexes to DNA is not exclusively a result of $\pi-\pi$ stacking interactions but rather a combination of this binding mode and an electrostatic and covalent interaction. Indication of more than one binding mode can be rationalised by the dual targeting nature if the complexes: via $\pi-\pi$ stacking interactions atop quadruplex DNA (with the metal-terpyridine core) as well as through electrostatic or covalent interactions (via the metal cyclen) to bases/phosphate backbone in the loops. Further structural studies are underway to establish the exact binding mode of these complexes with G-quadruplex DNA.

\section{Cytotoxicity of metal complexes}

Having established the high affinity of most of the complexes under investigation towards quadruplex DNA, we were interested in assessing their cytotoxicity. Thus MTS assays were carried out (using the CellTiter 96® AQueous Assay from Promega) on the complexes with two cell lines: human osteosarcoma (U2OS) and normal fibroblast (GM05757). U2OS cells expresses high levels of c-Myc protein making it a useful cell line for testing the anti-cancer properties of the synthesised quadruplex binders. GM05757 is a normal human fibroblast cell line which was used as a control. 
Table $4 \quad E_{50}$ values obtained for the metal(II) complexes against U2OS and GM07575 cell lines. The values are an average of three independent measurements

\begin{tabular}{lll}
\hline Compound & $\mathrm{U}^{2} \mathrm{OS} \mathrm{EC} \mathrm{E}_{50}(\mu \mathrm{M})$ & $\mathrm{GM}^{2} 07575 \mathrm{EC}_{50}(\mu \mathrm{M})$ \\
\hline $\mathbf{3}$ & $61 \pm 7$ & $130 \pm 12$ \\
$\mathbf{4}$ & $95 \pm 11$ & $225 \pm 26$ \\
$\mathbf{5}$ & $>500$ & $>500$ \\
$\mathbf{6}$ & $>500$ & $>500$ \\
$\mathbf{7}$ & $>500$ & $>500$ \\
$\mathbf{8}$ & $463 \pm 9$ & $339 \pm 81$ \\
$\mathbf{9}$ & $290 \pm 64$ & $155 \pm 7$ \\
$\mathbf{1 0}$ & $57 \pm 12$ & $121 \pm 5$ \\
$\mathbf{1 1}$ & $64 \pm 11$ & $132 \pm 8$ \\
$\mathbf{1 2}$ & $49 \pm 8$ & $95 \pm 1$ \\
$\mathbf{1 3}$ & $74 \pm 12$ & $180 \pm 15$ \\
$\mathbf{1 4}$ & $>500$ & $>500$ \\
$\mathbf{1 5}$ & $79 \pm 15$ & $98 \pm 5$ \\
Cisplatin & $48 \pm 6$ & $74 \pm 6$ \\
\end{tabular}

The $\mathrm{IC}_{50}$ values were determined for all the compounds under study with cisplatin employed as metal-containing control compound (Table 4). In general, the compounds had slightly higher toxicity towards the U2OS cells compared to GM05757 cell line. Under the conditions used, mono-platinum(II) complexes with chloride in the fourth coordination site $(\mathbf{3}, \mathbf{4}$, 10, 13 and 15) gave $\mathrm{EC}_{50}$ values ranging between 57 and $95 \mu \mathrm{M}$ for the U2OS cell line, which are comparable to cisplatin under the same conditions $\left(\mathrm{EC}_{50}=48 \mu \mathrm{M}\right)$. Similarly, the dimetallic complexes $\mathbf{1 1}$ and $\mathbf{1 2}$ which contain a [Pt(trpy)Cl$]^{+}$ unit, displayed high cytotoxicity against U2OS $\left(\mathrm{EC}_{50}=64\right.$ and $49 \mu \mathrm{M}$ respectively) while the di-zinc and di-copper complexes were less potent $\left(\mathrm{EC}_{50}=463\right.$ and $290 \mu \mathrm{M}$ respectively). On the other hand, platinum(II) complexes with thiolate in the fourth coordination position (5-7 and 14) were found to be non-toxic (up to a concentration of $500 \mu \mathrm{M}$ ) for the two cell lines. It is well established that platinum(II) complexes containing $\mathrm{Pt}-\mathrm{Cl}$ bonds (and more specifically $[\mathrm{Pt}(\text { trpy }) \mathrm{Cl}]^{+}$complexes), over time can hydrolyse to yield aquated complexes which eventually can coordinate to DNA. Therefore we propose that the high toxicity found for complexes 3, 4, 10, 13 and 15 may result from their ability to platinate DNA or perhaps some other biomolecules over time. Platinum(II)-thiol complexes, on the other hand, are relatively resistant to aquation because of their strong Pt-S bond and therefore do not platinate DNA sequences readily (see previous reports by Lippard et al. on the use of (trpy)Pt-thiolate complexes as metallo-intercaltors ${ }^{51-53}$ ). This probably explains their lack of toxicity against the cell lines tested over a $24 \mathrm{~h}$ period. The di-copper complex 9, on the other hand, displayed higher cytotoxicity against GM05757 cell line $(155 \pm 7 \mu \mathrm{M})$ than against U2OS $(290 \pm 64 \mu \mathrm{M})-$ although it should be noted that this is not particularly high for either of the two cell lines. The presence of copper(II) centres in this complex is likely to induce oxidative damage to DNA and hence the observed cytotoxicity might be due to this process rather than by targeting quadruplexes (for which 9 has a high affinity - see Table 2).

\section{Cellular uptake}

Cellular uptake studies were carried out to determine the cell permeability and localisation of a selection of the complexes. In particular, we were interested to establish whether the low cytotoxicity of compounds 7 and $\mathbf{1 4}$ (as representatives of the thiolated complexes) was due to their inability to aquate due to the thiolate being in the fourth coordination position rather than their inability to enter the cell. Thus, U2OS cells were incubated for $24 \mathrm{~h}$ at $37^{\circ} \mathrm{C}$ with sub-lethal concentrations $(10 \mu \mathrm{M})$ of two platinum-terpyridine complexes, 3 and 7 (with $\mathrm{Cl}$ and thiolate respectively in the fourth coordination position), and two platinum-phenanthroline complexes, 14 and 15 (with $\mathrm{Cl}$ and thiolate respectively in the fourth coordination position). The platinum content of the treated cells was determined for whole cell, nucleus and cytoplasm using inductively coupled plasma mass spectrometry (ICP-MS). Cellular platinum levels are expressed as ng of $\mathrm{Pt} / \mathrm{mg}$ of protein and the results reported are a mean of seven determinations for each data point (see Fig. 12).

The platinum(II)-terpyridine complexes (3 and 7) were found to be taken up by U2OS cells (between 5 and 15\% of the administered complexes at $10 \mu \mathrm{M})$. More importantly the complexes were also found to enter the nucleus $(>0.5 \mathrm{ng}$ of $\mathrm{Pt} / \mathrm{mg}$ of protein corresponding to $2-8 \%$ of the added complexes, was found in the nuclear fractions). The cellular uptake values are comparable to those obtained for other platinum(II) terpyridine-like complexes previously reported. ${ }^{5,55}$ Yet, for complex 7, cytotoxicity is low implying the thiolate effectively prevents non-specific coordination to proteins and/or DNA. The platinum(II) pyridyl-phenanthroline complex 15 was also taken up by the cells ( $4 \%$ of the administered amount). However, in contrast, the thiol functionalised platinum(II) pyridyl-phenanthroline complex 14 was not taken up by cells, consistent with its low cytotoxicity.

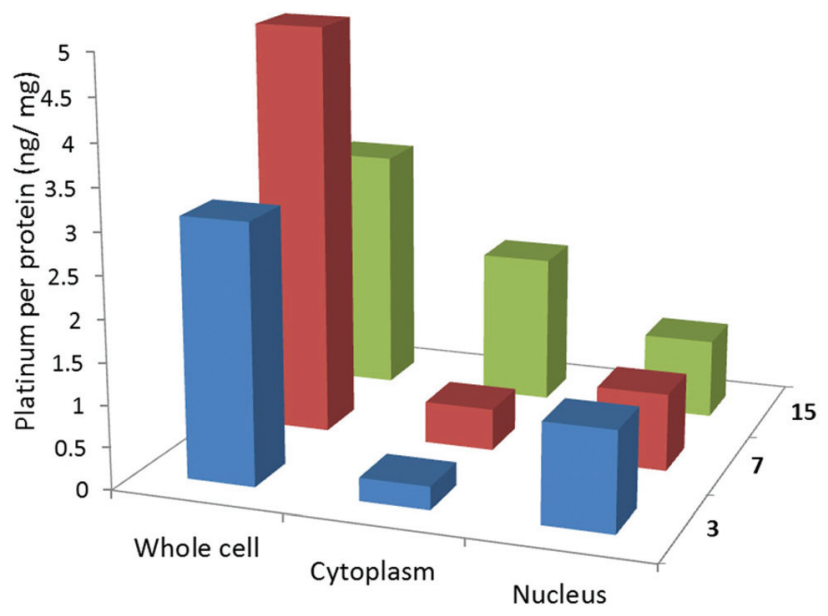

Fig. 12 Cellular uptake data for a selection of the complexes under study. The amount of platinum or copper (ng) per protein ( $\mathrm{mg}$ ) is expressed for the whole cell, cytoplasm and nucleus. 


\section{Conclusions}

Two new ligands and ten new metal complexes have been successfully prepared and their ability to bind to quadruplex DNA structures (c-Myc and HTelo) demonstrated. In general, most of the complexes were shown to bind $c-M y c$ quadruplex DNA more strongly than ct-DNA and also bind to $c-M y c$ quadruplex better than to Htelo quadruplex DNA. The complexes that display the highest affinity and selectivity for quadruplex DNA are those with the new terpyridine-cyclen ligand $\mathbf{L}^{\mathbf{4}}$. In particular, the bimetallic complexes containing a square planar $\mathrm{Pt}^{\mathrm{II}}$-terpy unit plus a copper(II) or zinc(II)-cyclen moiety, display very high affinities for $c-M y c$ quadruplex DNA (ca. $10^{8} \mathrm{M}^{-1}$ ) and up to 1000 -fold selectivity over ct-DNA. This is likely to be due to a dual type of interaction where the platinum-terpy complex binds via end stacking with the G-tetrad (at least initially) and the metal-cyclen unit interacts with the loops of the quadruplex. Interestingly, even complex 10, which contains a platinum-terpyridine moiety and a metal-free cyclen, displays very high affinities. It is possible that in this case the cyclen is highly protonated and therefore is able to display strong electrostatic interactions with the negativelycharged phosphate backbone of DNA.

For the platinum(II) complexes, we have shown that the nature of the ligand in the fourth coordination position plays an important role in their cytotoxicity. Complexes with chloride in the fourth coordination position have higher cytotoxicity than their thiolated counterparts. This is consistent with previous observations showing that $[\mathrm{Pt}(\operatorname{trpy}) \mathrm{Cl}]^{+}$complexes, once inside the cell, can be readily aquated and therefore platinate (by direct coordination) DNA.

Cellular uptake studies showed that complexes 3, 7 and $\mathbf{1 5}$ are taken up by U2OS cells and localise in the nucleus whereas phenanthroline-platinum complex $\mathbf{1 4}$ is not cell permeable. Therefore, these results indicate that the low cytotoxicity of $\mathbf{1 4}$ is associated with poor uptake. Conversely, the low cytotoxicity of 7 is not due to cell permeability issues. Hence it is proposed that the coordinated thiolate prevents it from platinating DNA. Further studies are underway to determine in more detail the quadruplex DNA binding mode of these complexes.

\section{Experimental section}

\section{General procedures}

${ }^{1} \mathrm{H}$ NMR, ${ }^{13} \mathrm{C}$ NMR and ${ }^{31} \mathrm{P}$ NMR spectra were recorded on a BrukerAvance $400 \mathrm{MHz}$ Ultrashield NMR spectrometer. Electron spray ionisation mass spectra were recorded on a BrukerDaltronics Esquire 3000 spectrometer. Elemental analysis of the compounds prepared was performed by Mr Alan Dickerson (University of Cambridge). Cyc-Tri-BOC, ${ }^{32} \mathbf{L}^{\mathbf{1}}-\mathbf{L}^{3}$ and $\mathbf{1 - 4} \mathbf{4}^{16,17}$ were prepared as previously reported. $\mathbf{L}^{\mathbf{1}}$ was purchased from Sigma Aldrich and its purity was checked by ${ }^{1} \mathrm{H}$ NMR spectroscopy prior to use. $\left[\operatorname{PtCl}\left(\mathbf{L}^{\mathbf{1}}\right)\right] \mathrm{Cl}, \mathbf{1 3}, \mathbf{L}^{\mathbf{5}}$ and $\mathbf{L}^{\mathbf{6}}$ were prepared by small modifications of reported procedures ${ }^{33,34,56}$ and their successful syntheses confirmed by comparing the spectro- scopic data with that reported in the literature. All oligonucleotides used were purchased from Eurogentec SA.

\section{Synthesis}

Synthesis of $\mathbf{L}^{4}$-BOC. A solution of Cyc-Tri-BOC ${ }^{32}(0.086 \mathrm{~g}$, $0.145 \mathrm{mmol})$ in acetone $(10 \mathrm{~mL})$ was added dropwise to a stirred refluxing mixture of 2,6-bis(2-pyridyl) $4(1 H)$ pyridone (0.037 g, $0.149 \mathrm{mmol})$ and potassium carbonate $(0.082 \mathrm{~g}$, $0.596 \mathrm{mmol})$ in acetone $(15 \mathrm{~mL})$. The stirred mixture was heated under reflux for $48 \mathrm{~h}$. After this time, the mixture was filtered to remove inorganic salts, water was added to the filtrate and the product was extracted into diethyl ether $(20 \mathrm{~mL} \times$ $2)$. The combined organic extracts were washed with water, $5 \%$ sodium hydroxide and water then dried with $\mathrm{Na}_{2} \mathrm{SO}_{4}$. The solvent was removed under reduced pressure to yield an off-white solid (81 mg, 74\%); ${ }^{1} \mathrm{H} \mathrm{NMR}$ (400 $\mathrm{MHz}, \mathrm{CDCl}_{3}$ ): $\delta_{\mathrm{H}} 8.71\left(\mathrm{~d}, 2 \mathrm{H},{ }^{3} J_{\mathrm{HH}}=8.0\right.$, tpy $\left.2-\mathrm{H}\right), 8.64\left(\mathrm{~d}, 2 \mathrm{H},{ }^{3} J_{\mathrm{HH}}=8.0\right.$, tpy $5-\mathrm{H}), 8.03$ (s, 2H, tpy' $3-\mathrm{H}$ and $5-\mathrm{H}), 7.88\left(\mathrm{dd}, 2 \mathrm{H},{ }^{3} J_{\mathrm{HH}}=8.0\right.$, 8.0, tpy 4-H), 7.37 (dd, $2 \mathrm{H},{ }^{3} \mathrm{~J}_{\mathrm{HH}}=8.0,8.0$, tpy $\left.3-\mathrm{H}\right), 4.28(\mathrm{t}, 2 \mathrm{H}$, ${ }^{3} J_{\mathrm{HH}}=6.0$, propyl $\left.3-\mathrm{H}\right), 3.60-2.60$ (br m, 16H, cyclen), $2.83(\mathrm{t}$, $2 \mathrm{H},{ }^{3} \mathrm{~J}_{\mathrm{HH}}=8.0$, propyl $\left.1-\mathrm{H}\right), 2.06(\mathrm{~m}, 2 \mathrm{H}$, propyl $2-\mathrm{H}), 1.48(\mathrm{~s}$, $27 \mathrm{H}$, Boc- $\left.-\mathrm{CH}_{3}\right) ;{ }^{13} \mathrm{C}$ NMR $\left(400 \mathrm{MHz}, \mathrm{CDCl}_{3}\right): \delta_{\mathrm{C}} 179.0,166.9$, 157.3, 156.1, 149.1, 136.6, 123.9, 121.3, 107.3, 79.5, 79.1, 66.6, 54.6, 54.3, 50.1, 49.1, 29.3, 23.9; ESI-MS Calcd for $\mathrm{C}_{41} \mathrm{H}_{59} \mathrm{~N}_{7} \mathrm{O}_{7}$ $[\mathrm{M}]^{+}$: 762 a.m.u. Found $[\mathrm{M}+\mathrm{H}]^{+}: 763$ a.m.u.

Synthesis of $\mathbf{L}^{\mathbf{4}}$. $\mathbf{L}^{\mathbf{4}}$-BOC $(0.045 \mathrm{~g}, 0.057 \mathrm{mmol})$ was dissolved in a solution of dichloromethane-TFA $(1: 1)(5 \mathrm{~mL})$ and stirred at room temperature for $24 \mathrm{~h}$. The solvents were then removed under reduced pressure and the resulting solid dried. This solid was then dissolved in water and $\mathrm{NaOH} 2 \mathrm{M}$ (aq) was added dropwise until the solution became alkaline $(\mathrm{pH} 12)$. The product was then extracted into dichloromethane. The solvent was removed under reduced pressure to yield a pale yellow sticky solid (0.016 g, 67\%); ${ }^{1} \mathrm{H}$ NMR (400 MHz, DMSO$\left.\mathrm{d}_{6}\right): \delta_{\mathrm{H}} 8.74\left(\mathrm{~d}, 2 \mathrm{H},{ }^{3} J_{\mathrm{HH}}=8.0\right.$, tpy $\left.2-\mathrm{H}\right), 8.66\left(\mathrm{~d}, 2 \mathrm{H},{ }^{3} J_{\mathrm{HH}}=8.0\right.$, tpy $5-\mathrm{H}), 8.06\left(\mathrm{dd}, 2 \mathrm{H},{ }^{3} J_{\mathrm{HH}}=8.0,8.0\right.$, tpy $\left.4-\mathrm{H}\right), 8.02\left(\mathrm{~s}, 2 \mathrm{H}, \mathrm{tpy}^{\prime}\right.$ $3-\mathrm{H}$ and $5-\mathrm{H}), 7.55\left(\mathrm{dd}, 2 \mathrm{H},{ }^{3} J_{\mathrm{HH}}=8.0,8.0\right.$, tpy $\left.3-\mathrm{H}\right), 4.32(\mathrm{t}$, $2 \mathrm{H},{ }^{3} \mathrm{~J}_{\mathrm{HH}}=4.0$, propyl 3-H), 3.12-2.82 (br m, 16H, cyclen), 2.92 $\left(\mathrm{t}, 2 \mathrm{H}, 3_{\mathrm{HH}}=4.0\right.$, propyl 1-H), $2.01(\mathrm{~m}, 2 \mathrm{H}$, propyl 2-H); (for COSY ${ }^{1} \mathrm{H}-{ }^{1} \mathrm{H}$ NMR see Fig. S1 in ESI $\dagger$ ); ${ }^{13} \mathrm{C}$ NMR $(400 \mathrm{MHz}$, DMSO-d $\left.{ }_{6}\right): \delta_{\mathrm{C}} 166.6,156.3,154.6,148.9,137.0,124.2,120.8$, 106.4, 65.7, 51.4, 50.5, 47.3, 46.0, 44.9, 26.0; ${ }^{19} \mathrm{~F} \quad \mathrm{NMR}$ (400 MHz, DMSO- $\mathrm{d}_{6}$ ): absence of peak at $\delta_{\mathrm{F}}-77.8$ indicates no triflate left; IR ( $\left.\mathrm{cm}^{-1}\right): 1672,1585,1565,1464,1444,1420$, 1393, 1198, 1127, 1008, 871, 828, 794, 744, 719; ESI-MS Calcd for $\mathrm{C}_{26} \mathrm{H}_{35} \mathrm{~N}_{7} \mathrm{O}[\mathrm{M}]^{+}: 461$ a.m.u. Found $[\mathrm{M}+\mathrm{H}]^{+}: 462$ a.m.u.

Synthesis of $\mathbf{L}^{7}$. 5-Chloro-1,10-phenanthroline $(200 \mathrm{mg}$, $0.94 \mathrm{mmol}$ ) and 1-(2-hydroxyethyl)piperidine (146 mg, $0.94 \mathrm{mmol}$ ) were slowly added to a stirred suspension of powered $\mathrm{KOH}(264 \mathrm{mg}, 5.0 \mathrm{mmol})$ in DMSO $(5 \mathrm{ml})$. The solution was stirred under nitrogen at $60{ }^{\circ} \mathrm{C}$ for $4 \mathrm{~h}$. The reaction mixture was extracted with $\mathrm{CH}_{2} \mathrm{Cl}_{2}(50 \mathrm{ml} \times 3)$, washed thoroughly with water $(30 \mathrm{ml} \times 3)$ and dried over sodium sulphate. The solvent was removed under reduced pressure to yield the product as a brown solid (212 $\mathrm{mg}, 73 \%) ;{ }^{1} \mathrm{H}$ NMR $\left(400 \mathrm{MHz}, \mathrm{CDCl}_{3}\right): \delta_{\mathrm{H}} 9.23\left(\mathrm{dd}, 1 \mathrm{H},{ }^{3} J_{\mathrm{HH}}=6.0,2.0\right.$, phen $\left.2-\mathrm{H}\right)$, 
$9.05\left(\mathrm{dd}, 1 \mathrm{H},{ }^{3} J_{\mathrm{HH}}=6.0,2.0\right.$, phen' $\left.2-\mathrm{H}\right), 8.71\left(\mathrm{dd}, 1 \mathrm{H},{ }^{3} \mathrm{~J}_{\mathrm{HH}}=\right.$ 8.0, 2.0, phen $4-\mathrm{H}), 8.14\left(\mathrm{dd}, 1 \mathrm{H},{ }^{3} J_{\mathrm{HH}}=8.0,2.0\right.$, phen' $\left.4-\mathrm{H}\right)$, $7.68\left(\mathrm{dd}, 1 \mathrm{H},{ }^{3} J_{\mathrm{HH}}=8.0,4.0\right.$, phen $\left.3-\mathrm{H}\right), 7.59\left(\mathrm{dd}, 1 \mathrm{H},{ }^{3} J_{\mathrm{HH}}=\right.$ 8.0, 4.0, phen' $3-\mathrm{H}), 7.00(\mathrm{~s}, 1 \mathrm{H}$, phen $5-\mathrm{H}), 4.44\left(\mathrm{t}, 2 \mathrm{H},{ }^{3} \mathrm{~J}_{\mathrm{HH}}=\right.$ 6.0, ethyl 1- $\mathrm{H}), 3.03\left(\mathrm{t}, 2 \mathrm{H},{ }^{3} J_{\mathrm{HH}}=6.0\right.$, ethyl $\left.2-\mathrm{H}\right), 2.65(\mathrm{~m}, 4 \mathrm{H}$, pip 1-H), 1.67 (m, 4H, pip 2-H), 1.51 (m, 2H, pip $3-\mathrm{H}) ;{ }^{13} \mathrm{C}$ NMR (400 MHz, DMSO-d 6 ): $\delta_{\mathrm{C}} 152.1,150.6,147.9,134.6,130.9$, 129.2, 123.7, 123.2, 122.6, 101.7, 66.9, 57.8, 55.2, 26.0, 24.1; ESI-MS Calcd for $\mathrm{C}_{19} \mathrm{H}_{21} \mathrm{~N}_{3} \mathrm{O}[\mathrm{M}]^{+}: 307.2$ a.m.u. Found $[\mathrm{M}+$ $\mathrm{H}^{+}$: 308.0 a.m.u.; Anal. Calcd for $\mathrm{C}_{19} \mathrm{H}_{21} \mathrm{~N}_{3} \mathrm{O} \cdot 1.45 \mathrm{H}_{2} \mathrm{O}: \mathrm{C} 68.42$, H 7.22, N 12.60; Found: C 68.86, H 6.76, N 12.58.

Synthesis of $\mathbf{L}^{\mathbf{8}}$. ${ }^{n}$ Butyl-lithium (2 M solution in cyclohexane, $0.81 \mathrm{ml}, 1.63 \mathrm{mmol}$ ) was added dropwise to a solution of 2-bromopyridine $(0.16 \mathrm{ml}, 1.63 \mathrm{mmol})$ in dry THF $(7 \mathrm{ml})$ under nitrogen at $-78{ }^{\circ} \mathrm{C}$. The resultant deep red solution was stirred for $15 \mathrm{~min}$. A solution of $\mathbf{L}^{7}(100 \mathrm{mg}, 0.33 \mathrm{mmol})$ in dry THF ( $5 \mathrm{ml}$ ) was then added via a cannula to the lithiated reaction mixture. The reaction was allowed to proceed for $2.5 \mathrm{~h}$. After this period, water $(30 \mathrm{ml})$ was added to quench the reaction and the organic material was extracted with DCM (50 $\mathrm{ml} \times$ $3)$. The reaction products were re-oxidised by incubating the DCM solution with $\mathrm{MnO}_{4}(3 \mathrm{~g})$ for $2 \mathrm{~h} . \mathrm{MnO}_{4}$ was filtered and then dried using $\mathrm{NaSO}_{4}$. The solvent was then removed under reduced pressure to give the crude product as a brown oil. The crude product was purified by alumina column chromatography using a THF-hexane- $\mathrm{Et}_{3} \mathrm{~N}(5: 1: 0.02)$ solvent system to give $\mathbf{L}^{8}$ as an off-white oily-solid (0.21 g, 21\%); ${ }^{1} \mathrm{H}$ NMR $\left(400 \mathrm{MHz}, \mathrm{CDCl}_{3}\right): \delta_{\mathrm{H}} 9.09\left(\mathrm{dd}, 1 \mathrm{H},{ }^{3} J_{\mathrm{HH}}=4.0,2.0\right.$, phen $\left.2-\mathrm{H}\right)$, $9.02\left(\mathrm{dd}, 1 \mathrm{H},{ }^{3} J_{\mathrm{HH}}=8.0\right.$, pyridyl $\left.2-\mathrm{H}\right), 8.83(\mathrm{~s}, 1 \mathrm{H}$, phen $7-\mathrm{H})$, $8.82\left(\mathrm{~d}, 1 \mathrm{H},{ }^{3} J_{\mathrm{HH}}=4.0\right.$, phen $\left.9-\mathrm{H}\right), 8.78\left(\mathrm{dd}, 1 \mathrm{H},{ }^{3} J_{\mathrm{HH}}=4.0,2.0\right.$, phen $4-\mathrm{H}), 8.15\left(\mathrm{dd}, 1 \mathrm{H},{ }^{3} J_{\mathrm{HH}}=4.0,2.0\right.$, phen $\left.10-\mathrm{H}\right), 7.94(\mathrm{td}$, $1 \mathrm{H},{ }^{3} J_{\mathrm{HH}}=4.0,2.0$, pyridyl $\left.4-\mathrm{H}\right), 7.60\left(\mathrm{dd}, 1 \mathrm{H},{ }^{3} J_{\mathrm{HH}}=4.0,2.0\right.$, pyridyl 3-H), $7.40\left(\mathrm{dd}, 1 \mathrm{H},{ }^{3} J_{\mathrm{HH}}=4.0,2.0\right.$, phen $\left.3-\mathrm{H}\right), 7.28(\mathrm{~m}$, $1 \mathrm{H}$, pyridyl 5-H), $4.46\left(\mathrm{t}, 2 \mathrm{H},{ }^{3} J_{\mathrm{HH}}=6.0\right.$, ethyl $\left.1-\mathrm{H}\right), 3.06(\mathrm{t}, 2 \mathrm{H}$, ${ }^{3} J_{\mathrm{HH}}=6.0$, ethyl 2-H), $2.66(\mathrm{~m}, 4 \mathrm{H}$, pip 1-H), $1.68(\mathrm{~m}, 4 \mathrm{H}$, pip 2-H), 1.51 (m, 2H, pip 3-H); ESI-MS Calcd for $\mathrm{C}_{24} \mathrm{H}_{24} \mathrm{~N}_{4} \mathrm{O}[\mathrm{M}]^{+}$: 384.2 a.m.u. Found $[\mathrm{M}+\mathrm{Na}]^{+}: 407.0$ a.m.u.

Synthesis of 5 . $\left[\mathrm{PtCl}\left(\mathbf{L}^{\mathbf{1}}\right)\right] \mathrm{Cl}(100 \mathrm{mg}, 0.19 \mathrm{mmol})$ and $\mathbf{L}^{\mathbf{5}}$ (108 $\mathrm{mg}, 0.76 \mathrm{mmol})$ were stirred in water $(10 \mathrm{ml})$ at room temperature for $48 \mathrm{~h}$ to afford a deep purple solution. After removing excess thiol by extraction with diethyl ether $(10 \mathrm{ml} \times 3)$ the aqueous layer was removed under reduced pressure. The resultant solid was washed thoroughly with diethyl ether $(20 \mathrm{ml})$. The desired complex was isolated as dark red crystals (80 mg, 71\%); ${ }^{1} \mathrm{H}$ NMR $\left(400 \mathrm{MHz}, \mathrm{D}_{2} \mathrm{O}\right): \delta_{\mathrm{H}} 8.93\left(\mathrm{~d}, 2 \mathrm{H},{ }^{3} \mathrm{~J}_{\mathrm{HH}}=\right.$ 6.0 , tpy $2-\mathrm{H}), 8.29\left(\mathrm{t}, 1 \mathrm{H},{ }^{3} J_{\mathrm{HH}}=8.0\right.$, tpy' $\left.4-\mathrm{H}\right), 8.24\left(\mathrm{t}, 2 \mathrm{H},{ }^{3} J_{\mathrm{HH}}\right.$ $=8.0,4.0$, tpy $4-\mathrm{H}), 8.11\left(\mathrm{~d}, 2 \mathrm{H},{ }^{3} J_{\mathrm{HH}}=8.0\right.$, tpy $\left.5-\mathrm{H}\right), 8.07(\mathrm{~d}$, $2 \mathrm{H},{ }^{3} J_{\mathrm{HH}}=8.0$, tpy' $3-\mathrm{H}$ and $\left.5-\mathrm{H}\right), 7.68\left(\mathrm{t}, 2 \mathrm{H},{ }^{3} J_{\mathrm{HH}}=6.0,4.0\right.$, tpy $3-\mathrm{H}), 3.18\left(\mathrm{~m}, 3 \mathrm{H}\right.$, ethyl $1-\mathrm{H}$ and pip $\left.\mathrm{N}^{+}-\mathrm{H}\right), 2.99$ (br s, $4 \mathrm{H}$, pip 1-H), $2.63\left(\mathrm{t}, 2 \mathrm{H},{ }^{3} J_{\mathrm{HH}}=8.0\right.$, ethyl $\left.2-\mathrm{H}\right), 1.62$ (br s, 4H, pip 2-H), 1.45 (br s, 2H, pip 3-H); ${ }^{13} \mathrm{C}$ NMR (400 MHz, $\mathrm{D}_{2} \mathrm{O}$ ): $\delta_{\mathrm{C}} 158.78,153.40,152.19,142.70,129.53,129.12,126.02$, 124.45, 59.59, 52.52, 23.68, 22.86, 21.43; ESI-MS Calcd for $\mathrm{C}_{22} \mathrm{H}_{26} \mathrm{Cl}_{2} \mathrm{~N}_{4} \mathrm{PtS}[\mathrm{M}]^{+}$: 643.2 a.m.u. Found $[\mathrm{M}-2 \mathrm{Cl}]^{+}: 572.0$ a.m.u.; Anal. Calcd for $\mathrm{C}_{22} \mathrm{H}_{26} \mathrm{Cl}_{2} \mathrm{~N}_{4} \mathrm{PtS} \cdot 3 \mathrm{H}_{2} \mathrm{O}$ : C 37.83, $\mathrm{H} 4.62$, $\mathrm{N}$ 8.02; Found: C 37.83, H 4.22, N 7.82.
Synthesis of 6. Complex $3(100 \mathrm{mg}, 0.16 \mathrm{mmol})$ and $\mathbf{L}^{5}$ $(139 \mathrm{mg}, 0.96 \mathrm{mmol})$ were stirred in water $(15 \mathrm{ml})$ at $40{ }^{\circ} \mathrm{C}$ for $48 \mathrm{~h}$ to afford an orange solution. After removing excess thiol by extraction with diethyl ether $(20 \mathrm{ml} \times 3)$ the aqueous layer was removed under reduced pressure. The resultant solid was purified by alumina column chromatography using 100\% DCM to give the product as a chloride salt. In order to form the $\mathrm{PF}_{6}$ salt the solid was dissolved in the minimum amount of DMSO, to which excess $\mathrm{NaPF}_{6}$ (as an aqueous solution) was added dropwise. This yielded a red precipitate which was isolated by filtration and washed repeatedly diethyl ether. The diarm complex was isolated as an orange powder (15 mg, 13\%); ${ }^{1} \mathrm{H}$ NMR (400 MHz, DMSO-d 6 ): $\delta_{\mathrm{H}} 9.40\left(\mathrm{~d}, 2 \mathrm{H},{ }^{3} \mathrm{~J}_{\mathrm{HH}}=4.0\right.$, tpy $2-\mathrm{H}), 8.73\left(\mathrm{~d}, 2 \mathrm{H},{ }^{3} \mathrm{~J}_{\mathrm{HH}}=6.0\right.$, tpy $\left.5-\mathrm{H}\right), 8.59\left(\mathrm{t}, 2 \mathrm{H},{ }^{3} J_{\mathrm{HH}}=6.0\right.$, tpy $4-\mathrm{H}), 8.42\left(\mathrm{~s}, 2 \mathrm{H}, \mathrm{tpy} \mathrm{y}^{\prime} 3-\mathrm{H}\right.$ and $\left.5^{\prime}-\mathrm{H}\right), 8.03\left(\mathrm{t}, 2 \mathrm{H},{ }^{3} J_{\mathrm{HH}}=6.0\right.$, tpy $3-\mathrm{H}), 4.77\left(\mathrm{t}, 2 \mathrm{H},{ }^{3} J_{\mathrm{HH}}=4.0\right.$, O-ethyl 1-H), $3.70\left(\mathrm{t}, 2 \mathrm{H},{ }^{3} J_{\mathrm{HH}}=\right.$ 4.0, O-ethyl 2-H), 3.60 (br s, 4H, O-pip 1-H), 3.12 (m, 2H, S-ethyl 1-H), 2.82 (m, 2H, S-ethyl 2-H), 1.90 (m, 4H, S-pip 1-H), 1.74 (m, 10H, S-pip 2-H, O-pip 2-H and pip $\left.\mathrm{N}^{+}-\mathrm{H}\right), 1.55$ (m, 4H, S-pip 3-H, O-pip 3-H); ${ }^{31} \mathrm{P}$ NMR (400 MHz, DMSO-d 6 ): $\delta_{\mathrm{P}}-144.19$ (sept, 3P, ${ }^{1} J_{\mathrm{PF}}=1760, \mathrm{PF}_{6}$ ); ESI-MS Calcd for $\mathrm{C}_{29} \mathrm{H}_{40} \mathrm{~F}_{18} \mathrm{~N}_{5} \mathrm{OP}_{3} \mathrm{PtS}[\mathrm{M}]^{+}: 1135.2$ a.m.u. Found $\left[\mathrm{M}-\mathrm{PF}_{6}\right]^{+}$: 991.0 a.m.u., $\left[\mathrm{M}-2 \mathrm{PF}_{6}\right]^{+}: 846.0$ a.m.u., $\left[\mathrm{M}-3 \mathrm{PF}_{6}\right]^{+}: 699.2$ a.m.u.; Anal. Calcd for $\mathrm{C}_{29} \mathrm{H}_{40} \mathrm{~F}_{18} \mathrm{~N}_{5} \mathrm{OP}_{3} \mathrm{PtS} \cdot \mathrm{H}_{2} \mathrm{O}$ : C 30.16, H 3.67, N 6.07; Found: C 29.71, H 3.63, N 5.71.

Synthesis of 7. Complex $4(100 \mathrm{mg}, 0.16 \mathrm{mmol})$ and $\mathbf{L}^{5}$ $(139 \mathrm{mg}, 0.96 \mathrm{mmol})$ were stirred in water $(15 \mathrm{ml})$ at $40{ }^{\circ} \mathrm{C}$ for $48 \mathrm{~h}$ to afford an orange solution. After removing excess thiol by extraction with diethyl ether $(20 \mathrm{ml} \times 3)$ the aqueous layer was removed under reduced pressure. The resultant solid was dissolved in the minimum amount of DMSO, to which excess $\mathrm{NaPF}_{6}$ (as an aqueous solution) was added dropwise. This yielded a red precipitate which was isolated by filtration and washed repeatedly diethyl ether. The di-arm complex was isolated as an orange powder (23 mg, 21\%); ${ }^{1} \mathrm{H}$ NMR $(400 \mathrm{MHz}$, DMSO-d $\left.{ }_{6}\right): \delta_{\mathrm{H}} 9.39\left(\mathrm{~d}, 2 \mathrm{H},{ }^{3} J_{\mathrm{HH}}=4.0\right.$, tpy $\left.2-\mathrm{H}\right), 8.70(\mathrm{~d}, 2 \mathrm{H}$, ${ }^{3} J_{\mathrm{HH}}=6.0$, tpy $\left.5-\mathrm{H}\right), 8.57\left(\mathrm{t}, 2 \mathrm{H},{ }^{3} J_{\mathrm{HH}}=6.0\right.$, tpy $\left.4-\mathrm{H}\right), 8.41(\mathrm{~s}$, $2 \mathrm{H}$, tpy' $3-\mathrm{H}$ and $5-\mathrm{H}), 8.01\left(\mathrm{t}, 2 \mathrm{H},{ }^{3} \mathrm{~J}_{\mathrm{HH}}=6.0\right.$, tpy $\left.3-\mathrm{H}\right), 4.70(\mathrm{br}$ s, 2H, O-ethyl 1-H), 4.07 (br s, 2H, O-ethyl 2-H), 3.76 (br s, $4 \mathrm{H}$, O-mor, 1-H), 3.60 (br s, 4H, O-mor, 2-H), 3.09 (t, 2H, ${ }^{3} J_{\mathrm{HH}}=8.0$, S-ethyl 1-H), $2.95\left(\mathrm{t}, 2 \mathrm{H},{ }^{3} J_{\mathrm{HH}}=8.0\right.$, Sethyl 2-H), $2.82(\mathrm{~m}, 4 \mathrm{H}$, S-pip, 1-H), 1.78 (m, 4H, S-pip, 2-H), 1.61 (m, 2H, pip $\mathrm{N}^{+}-\mathrm{H}$ and mor $\mathrm{N}^{+}-\mathrm{H}$ ), 1.33 (m, 2H, S-pip 3-H); ${ }^{31} \mathrm{P}$ NMR (400 MHz, DMSO-d ${ }_{6}$ ): $\delta_{\mathrm{P}}-144.20$ (sept, $3 \mathrm{P},{ }^{1} J_{\mathrm{PF}}=1752, \mathrm{PF}_{6}$ ); ESI-MS Calcd $\mathrm{C}_{28} \mathrm{H}_{38} \mathrm{~F}_{18} \mathrm{~N}_{5} \mathrm{O}_{2} \mathrm{P}_{3} \mathrm{PtS}[\mathrm{M}]^{+}: 1136.1$ a.m.u. Found $\left[\mathrm{M}-\mathrm{PF}_{6}\right]^{+}$: 993.2 a.m.u., $\left[\mathrm{M}-2 \mathrm{PF}_{6}\right]^{+}: 847.2$ a.m.u., $\left[\mathrm{M}-3 \mathrm{PF}_{6}\right]^{+}: 701.2$ a.m.u.; Anal. Calcd for $\mathrm{C}_{28} \mathrm{H}_{38} \mathrm{~F}_{18} \mathrm{~N}_{5} \mathrm{O}_{2} \mathrm{P}_{3} \mathrm{PtS} \cdot 3 \mathrm{H}_{2} \mathrm{O}$ : C $28.20, \mathrm{H}$ 3.72, N 5.87; Found: C 28.02, H 3.44, N 5.50.

Synthesis of 8. $\mathbf{L}^{4}(0.020 \mathrm{~g}, 0.043 \mathrm{mmol})$ was dissolved in methanol $(3 \mathrm{ml})$ and added to a solution of $\mathrm{ZnCl}_{2}(0.012 \mathrm{~g}$, $0.086 \mathrm{mmol})$ in methanol $(2 \mathrm{~mL})$. A white precipitate was seen to form immediately. The solution was heated to $40{ }^{\circ} \mathrm{C}$ and set to stir for $48 \mathrm{~h}$. The solution was then allowed to cool and the off-white solid was filtered and washed with methanol and diethyl ether and dried under vacuo $(0.022 \mathrm{~g}, 71 \%) ;{ }^{1} \mathrm{H}$ NMR $\left(400 \mathrm{MHz}, \mathrm{DMSO}_{6}\right): \delta_{\mathrm{H}} 8.81\left(\mathrm{~d}, 2 \mathrm{H},{ }^{3} J_{\mathrm{HH}}=8.0\right.$, tpy $\left.2-\mathrm{H}\right), 8.79$ 
$\left(\mathrm{d}, 2 \mathrm{H},{ }^{3} J_{\mathrm{HH}}=8.0\right.$, tpy $\left.5-\mathrm{H}\right), 8.37\left(\mathrm{~s}, 2 \mathrm{H}, \mathrm{tpy}^{\prime} 3-\mathrm{H}\right.$ and $\left.5-\mathrm{H}\right), 8.33$ $\left(\mathrm{dd}, 2 \mathrm{H},{ }^{3} \mathrm{~J}_{\mathrm{HH}}=8.0,8.0\right.$, tpy $\left.4-\mathrm{H}\right), 7.88\left(\mathrm{dd}, 2 \mathrm{H},{ }^{3} J_{\mathrm{HH}}=8.0,8.0\right.$, tpy $3-\mathrm{H}$ ), 4.50 (br, $2 \mathrm{H}$, propyl $3-\mathrm{H}$ ), 3.00-2.60 (br m, $18 \mathrm{H}$, cyclen and propyl 1-H), 2.21 (m, 2H, propyl 2-H); (for COSY ${ }^{1} \mathrm{H}-{ }^{1} \mathrm{H}$ NMR see Fig. S1 in ESI $\left.\dagger\right) ;{ }^{13} \mathrm{C}$ NMR (400 MHz, DMSO$\left.\mathrm{d}_{6}\right): \delta_{\mathrm{C}} 170.0,150.3,148.8,147.0,140.5,127.0,122.0,109.2$, 68.4, 49.4, 49.1, 44.2, 43.2, 42.0, 21.7; ESI-MS Calcd for $\mathrm{C}_{26} \mathrm{H}_{35} \mathrm{Cl}_{5} \mathrm{Zn}_{2.5} \mathrm{~N}_{7} \mathrm{O}[\mathrm{M}]^{+}$: 797 a.m.u. Found $\left[\mathrm{M}-0.5 \mathrm{ZnCl}_{4}\right]^{+}$: 698 a.m.u.; Anal. Calcd for $\mathrm{C}_{26} \mathrm{H}_{35} \mathrm{Cl}_{5} \mathrm{~N}_{7} \mathrm{OZn}_{2.5} \cdot 2 \mathrm{H}_{2} \mathrm{O}: \mathrm{C}, 37.25$; H, 4.69; N, 11.69; Found: C 36.92, H 4.27, N 11.19.

Synthesis of $9 . \mathbf{L}^{4}(0.020 \mathrm{~g}, 0.043 \mathrm{mmol})$ was dissolved in methanol $(3 \mathrm{ml})$ and added to a solution of $\mathrm{CuCl}_{2} \cdot 2 \mathrm{H}_{2} \mathrm{O}$ $(0.015 \mathrm{~g}, 0.086 \mathrm{mmol})$ in methanol $(2 \mathrm{~mL})$. A blue precipitate was seen to form immediately. The solution was heated to $40{ }^{\circ} \mathrm{C}$ and set to stir for $48 \mathrm{~h}$. The solution was then allowed to cool and the blue solid was filtered and washed with diethyl ether and dried under vacuo $(0.021 \mathrm{~g}, 68 \%)$; IR $\left(\mathrm{cm}^{-1}\right): 1613$, 1563, 1475, 1441, 1366, 1225, 1081, 1058, 1040, 1022, 991, 858, 803, 726, 700; UV/Vis (DMSO) $\lambda_{\max } / \mathrm{nm}\left(\varepsilon / \mathrm{cm}^{-1} \mathrm{M}^{-1}\right): 317$ (11 080), 331 (8940); ESI-MS Calcd for $\mathrm{C}_{26} \mathrm{H}_{35} \mathrm{Cl}_{4} \mathrm{Cu}_{2} \mathrm{~N}_{7} \mathrm{O}[\mathrm{M}]^{+}$: 729 a.m.u. Found $[\mathrm{M}-\mathrm{Cl}]^{+}$: 694 a.m.u.; Anal. Calcd for $\mathrm{C}_{26} \mathrm{H}_{35} \mathrm{Cl}_{4} \mathrm{Cu}_{2} \mathrm{~N}_{7} \mathrm{O} \cdot 3 \mathrm{H}_{2} \mathrm{O}$ : C, 39.80; H, 5.27; N, 12.50; Found: $\mathrm{C}$ 39.44, H 4.96, N 12.24.

Synthesis of 10. $\mathbf{L}^{\mathbf{4}}(0.020 \mathrm{~g}, 0.043 \mathrm{mmol})$ was dissolved in DMSO $(2 \mathrm{~mL})$ and added to a solution of $\mathrm{K}_{2} \mathrm{PtCl}_{4}(0.020 \mathrm{mg}$, $0.047 \mathrm{mmol}$ ) in DMSO $(2 \mathrm{~mL})$. The solution was heated to $45^{\circ} \mathrm{C}$ and set to stir for $24 \mathrm{~h}$. The solution was then allowed to cool and acetone was added to precipitate out a yellow solid which was filtered, washed with acetone and dried. This solid $(0.018 \mathrm{~g}, 0.025 \mathrm{mmol})$ was dissolved in the minimum amount of DMSO and to this an aqueous solution of $\mathrm{NaPF}_{6}$ was added. This resulted in an orange precipitate which was filtered, washed with diethyl ether and dried. The product was obtained as a yellow solid $(0.023,73 \%) ;{ }^{1} \mathrm{H}$ NMR $(400 \mathrm{MHz}$, DMSO-d $\left.{ }_{6}\right): \delta_{\mathrm{H}} 9.02\left(\mathrm{~d}, 2 \mathrm{H},{ }^{3} J_{\mathrm{HH}}=8.0\right.$, tpy $\left.2-\mathrm{H}\right), 8.72(\mathrm{~d}, 2 \mathrm{H}$, ${ }^{3} J_{\mathrm{HH}}=8.0$, tpy $\left.5-\mathrm{H}\right), 8.57\left(\mathrm{dd}, 2 \mathrm{H},{ }^{3} J_{\mathrm{HH}}=8.0,8.0\right.$, tpy $\left.4-\mathrm{H}\right), 8.35$ (s, 2H, tpy' $3-\mathrm{H}$ and $5-\mathrm{H}), 8.01\left(\mathrm{dd}, 2 \mathrm{H},{ }^{3} \mathrm{~J}_{\mathrm{HH}}=8.0,8.0\right.$, py $\left.3-\mathrm{H}\right)$, $4.57\left(\mathrm{t}, 2 \mathrm{H},{ }^{3} \mathrm{~J}_{\mathrm{HH}}=8.0\right.$, propyl $\left.3-\mathrm{H}\right), 3.84\left(\mathrm{t}, 2 \mathrm{H},{ }^{3} J_{\mathrm{HH}}=8.0\right.$, propyl 1-H), 3.58-2.86 (br m, 16H, cyclen), 2.38 (m, 2H, propyl 2-H); ${ }^{31} \mathrm{P}$ NMR(400 MHz, DMSO-d 6 ): $\delta_{\mathrm{P}}-143.95$ (sep); IR $\left(\mathrm{cm}^{-1}\right):$ 1570, 1442, 1405, 1334, 1219, 998, 827; UV/Vis (DMSO) $\lambda_{\max } / \mathrm{nm}\left(\varepsilon / \mathrm{cm}^{-1} \mathrm{M}^{-1}\right): 320$ (7700), 334 (8120); ESI-MS Calcd for $\mathrm{C}_{26} \mathrm{H}_{38} \mathrm{ClF}_{6} \mathrm{~N}_{7} \mathrm{OP}_{4} \mathrm{Pt}[\mathrm{M}]^{+}: 1275$ a.m.u., Found $[\mathrm{M}]^{+}: 838$ a.m.u., $\left[\mathrm{M}-2 \mathrm{H}-3 \mathrm{PF}_{6}\right]^{+}: 838$ a.m.u.; Anal. Calcd for $\mathrm{C}_{26} \mathrm{H}_{38} \mathrm{ClF}_{24} \mathrm{~N}_{7} \mathrm{OP}_{4} \mathrm{Pt} \cdot 2 \mathrm{H}_{2} \mathrm{O}$ : C 23.82, $\mathrm{H}$ 3.23, N 7.48; Found: C 23.60, H 2.71, N 7.03.

Synthesis of 11. $\mathbf{L}^{4}(0.020 \mathrm{~g}, 0.043 \mathrm{mmol})$ was dissolved in dimethyl sulphoxide $(2 \mathrm{~mL})$ and added to a solution of $\mathrm{K}_{2} \mathrm{PtCl}_{4}$ (0.019 $\mathrm{mg}, 0.047 \mathrm{mmol})$ in dimethyl sulphoxide $(2 \mathrm{~mL})$. The solution was heated to $45^{\circ} \mathrm{C}$ and set to stir for $24 \mathrm{~h}$. To the resultant orange solution 1.1 eq. of $\mathrm{ZnCl}_{2}(0.0064 \mathrm{~g}$, $0.047 \mathrm{mmol}$ ) was added and the solution stirred for a further $24 \mathrm{~h}$ at $45^{\circ} \mathrm{C}$. An aqueous solution of $\mathrm{NaPF}_{6}$ was added directly to the reaction mixture which yielded a yellow precipitate, which was filtered, washed with diethyl ether and dried. The product was isolated as a yellow $\mathrm{PF}_{6}$ salt (0.026 g, 51\%);
${ }^{1} \mathrm{H}$ NMR (400 MHz, DMSO-d 6 ): $\delta_{\mathrm{H}} 9.01\left(\mathrm{~d}, 2 \mathrm{H},{ }^{3} \mathrm{~J}_{\mathrm{HH}}=8.0\right.$, tpy 2$\mathrm{H}), 8.70\left(\mathrm{~d}, 2 \mathrm{H},{ }^{3} J_{\mathrm{HH}}=8.0\right.$, tpy $\left.5-\mathrm{H}\right), 8.56\left(\mathrm{dd}, 2 \mathrm{H},{ }^{3} J_{\mathrm{HH}}=8.0\right.$, tpy $4-\mathrm{H}), 8.33\left(\mathrm{~s}, 2 \mathrm{H}, \mathrm{tpy}^{\prime} 3-\mathrm{H}\right.$ and $\left.5-\mathrm{H}\right), 8.01\left(\mathrm{dd}, 2 \mathrm{H},{ }^{3} J_{\mathrm{HH}}=\right.$ 8.0, 8.0, py $3-\mathrm{H}), 4.55\left(\mathrm{t}, 2 \mathrm{H},{ }^{3} J_{\mathrm{HH}}=4.0\right.$, propyl $\left.3-\mathrm{H}\right), 3.83(\mathrm{t}, 2 \mathrm{H}$, ${ }^{3} J_{\mathrm{HH}}=8.0$, propyl 1-H), 3.60-2.80 (br m, 16H, cyclen), 2.37 (m, 2H, propyl 2-H); COSY ${ }^{1} \mathrm{H}-{ }^{1} \mathrm{H}$ NMR (400 MHz, DMSO-d ${ }_{6}$ ): see appendix; ${ }^{13} \mathrm{C}$ NMR (400 MHz, DMSO-d 6 ): $\delta_{\mathrm{C}} 176.8,168.9$, 158.2, 155.6, 151.0, 142.2, 129.4, 125.5, 110.9, 68.0, 60.6, 54.7 53.0, 52.3, 50.6, 26.5; ${ }^{31} \mathrm{P} \quad \mathrm{NMR}\left(400 \mathrm{MHz}, \quad \mathrm{DMSO}-\mathrm{d}_{6}\right):$ $\delta_{\mathrm{p}}-144.40$ (sep); IR ( $\left.\mathrm{cm}^{-1}\right): 1610,1475,1429,1363,1220,1034$, 826, 779, 739; UV/Vis (DMSO) $\lambda_{\max } / \mathrm{nm}\left(\varepsilon / \mathrm{cm}^{-1} \mathrm{M}^{-1}\right): 319$ (9380), 334 (9480); ESI-MS Calcd for $\mathrm{C}_{26} \mathrm{H}_{35} \mathrm{ClF}_{18} \mathrm{~N}_{7} \mathrm{OP}_{3} \mathrm{PtZn}$ $[\mathrm{M}]^{+}: 1193$ a.m.u. Found $\left[\mathrm{M}-2 \mathrm{PF}_{6}+\mathrm{K}\right]^{+}$: 940 a.m.u.; Anal. Calcd For $\mathrm{C}_{26} \mathrm{H}_{35} \mathrm{ClF}_{18} \mathrm{~N}_{7} \mathrm{OP}_{3} \mathrm{PtZn} \cdot 4.8 \mathrm{H}_{2} \mathrm{O}: \mathrm{C}, 24.42 ; \mathrm{H}, 3.52$; $\mathrm{Cl}$, 2.77; N, 7.67; Found: C 24.97, H 3.05, N 7.17.

Synthesis of $12 . \mathbf{L}^{\mathbf{4}}(0.020 \mathrm{~g}, 0.043 \mathrm{mmol})$ was dissolved in dimethyl sulphoxide $(2 \mathrm{~mL})$ and added to a solution of $\mathrm{K}_{2} \mathrm{PtCl}_{4}$ (0.019 $\mathrm{mg}, 0.047 \mathrm{mmol}$ ) in dimethyl sulphoxide $(2 \mathrm{~mL})$. The solution was heated to $45{ }^{\circ} \mathrm{C}$ and set to stir for $24 \mathrm{~h}$. To the resultant orange solution 1.1 eq. of $\mathrm{CuCl}_{2} \cdot 2 \mathrm{H}_{2} \mathrm{O}(0.0080 \mathrm{~g}$, $0.047 \mathrm{mmol}$ ) was added and the solution stirred for a further $24 \mathrm{~h}$ at $45{ }^{\circ} \mathrm{C}$. During this time the colour of the solution turned from yellow to a pale green. An aqueous solution of $\mathrm{NaPF}_{6}$ was added directly to the reaction mixture which yielded a green precipitate, which was filtered, washed with diethyl ether and dried. The product was isolated as a pale green $\mathrm{PF}_{6}$ salt $(0.031 \mathrm{~g}, 61 \%)$; IR $\left(\mathrm{cm}^{-1}\right)$ : 1621, 1428, 1205, 1035, 831, 779, 741; UV/Vis (DMSO) $\lambda_{\max } / \mathrm{nm}\left(\varepsilon / \mathrm{cm}^{-1} \mathrm{M}^{-1}\right): 319$ (11 500), 334 (12 240); ESI-MS Calcd for $\mathrm{C}_{26} \mathrm{H}_{35} \mathrm{ClCuF}_{18} \mathrm{~N}_{7} \mathrm{OP}_{3} \mathrm{Pt}$ $[\mathrm{M}]^{+}: 1189$ a.m.u. Found $\left[\mathrm{M}-\mathrm{PF}_{6}\right]^{+}: 1450$ a.m.u.; Anal. Calcd For $\mathrm{C}_{26} \mathrm{H}_{35} \mathrm{ClCuF}_{18} \mathrm{~N}_{7} \mathrm{OP}_{3} \mathrm{Pt} \cdot 4 \mathrm{H}_{2} \mathrm{O} \cdot \mathrm{NaCl}: \mathrm{C}, 23.64 ; \mathrm{H}, 3.28 ; \mathrm{N}$, 7.42; Found: C 23.45, H 2.83, N 7.04 .

Synthesis of 14. Compound $13(25 \mathrm{mg}, 0.048 \mathrm{mmol})$ and $\mathbf{L}^{\mathbf{5}}$ (35 mg, $0.240 \mathrm{mmol}$ ) were stirred in water $(5 \mathrm{ml})$ at $40{ }^{\circ} \mathrm{C}$ for $48 \mathrm{~h}$ to afford an orange solution. After removing excess thiol by extraction with diethyl ether $(10 \mathrm{ml} \times 3)$ the aqueous layer was removed under reduced pressure. The resultant solid was dissolved in the minimum amount of DMSO, to which excess $\mathrm{NaPF}_{6}$ (as an aqueous solution) was added dropwise. This yielded a purple precipitate which was isolated by filtration and washed repeatedly with water and diethyl ether. The mono-arm complex was isolated as an purple powder $(28 \mathrm{mg}$, $66 \%$ ); ${ }^{1} \mathrm{H}$ NMR (400 MHz, DMSO-d ${ }_{6}$ ): $\delta_{\mathrm{H}} 9.39\left(\mathrm{~d}, 1 \mathrm{H},{ }^{3} J_{\mathrm{HH}}=\right.$ 8.0, phen 2-H), $9.35\left(\mathrm{~d}, 1 \mathrm{H},{ }^{3} J_{\mathrm{HH}}=4.0\right.$, pyridyl $\left.2-\mathrm{H}\right), 9.22(\mathrm{~d}$, $1 \mathrm{H},{ }^{3} J_{\mathrm{HH}}=8.0$, phen $\left.9-\mathrm{H}\right), 9.10\left(\mathrm{~d}, 1 \mathrm{H},{ }^{3} J_{\mathrm{HH}}=8.0\right.$, phen $\left.4-\mathrm{H}\right)$, $8.94\left(\mathrm{~d}, 1 \mathrm{H},{ }^{3} J_{\mathrm{HH}}=8.0\right.$, phen $\left.10-\mathrm{H}\right), 8.80\left(\mathrm{~d}, 1 \mathrm{H},{ }^{3} J_{\mathrm{HH}}=4.0\right.$, pyridyl $5-\mathrm{H}), 8.59\left(\mathrm{t}, 1 \mathrm{H},{ }^{3} J_{\mathrm{HH}}=8.0\right.$, phen $\left.3-\mathrm{H}\right), 8.38(\mathrm{dd}, 2 \mathrm{H}$, ${ }^{3} J_{\mathrm{HH}}=8.0$, phen $6-\mathrm{H}$ and $\left.7-\mathrm{H}\right), 8.27\left(\mathrm{dd}, 1 \mathrm{H},{ }^{3} J_{\mathrm{HH}}=8.0,4.0\right.$, pyridyl 3-H), $8.05\left(\mathrm{t}, 1 \mathrm{H},{ }^{3} J_{\mathrm{HH}}=8.0\right.$, pyridyl $\left.4-\mathrm{H}\right), 2.92(\mathrm{~m}, 2 \mathrm{H}$, ethyl 1-H), $2.81\left(\mathrm{~m}, 2 \mathrm{H}\right.$, ethyl 2-H), $2.67\left(\mathrm{~m}, 1 \mathrm{H}\right.$, pip $\left.\mathrm{N}^{+}-\mathrm{H}\right)$, 1.74 (m, H, pip 1-H), 1.59 (m, 6H, pip 2-H and $3-\mathrm{H}) ;{ }^{31} \mathrm{P}$ NMR (400 MHz, DMSO-d $_{6}$ ): $\delta_{\mathrm{P}}-144.8$ (sept, $2 \mathrm{P},{ }^{1} J_{\mathrm{P}-\mathrm{F}}=1756, \mathrm{PF}_{6}$ ); ESI-MS Calcd for $\mathrm{C}_{24} \mathrm{H}_{25} \mathrm{~F}_{12} \mathrm{~N}_{4} \mathrm{P}_{2} \mathrm{PtS}[\mathrm{M}]^{+}$: 886.6 a.m.u. Found $\left[\mathrm{M}+3 \mathrm{H}^{+}-2 \mathrm{PF}_{6}\right]^{+}: 623.0$ a.m.u.; Anal. Calcd for $\mathrm{C}_{24} \mathrm{H}_{25} \mathrm{~F}_{12} \mathrm{~N}_{4} \mathrm{P}_{2}$ PtS·2HCl: C 30.04, $\mathrm{H}$ 2.84, N 5.84; Found: $\mathrm{C}$ 29.52, H 2.83, N 5.21. 
Synthesis of 15 . Ligand $\mathbf{L}^{8}(50 \mathrm{mg}, 0.13 \mathrm{mmol})$ and $\left[\mathrm{PtCl}_{2}(\mathrm{COD})\right](49 \mathrm{mg}, 0.13 \mathrm{mmol})$ were placed in water $(7 \mathrm{ml})$ and stirred at $75{ }^{\circ} \mathrm{C}$ for $3 \mathrm{~h}$. During this time the reactants completely dissolved giving a yellow solution. Upon cooling the reaction mixture a saturated aqueous solution of $\mathrm{NaPF}_{6}$ was added to give the product as an orange solid. The solid was filtered and washed thoroughly with water $(10 \mathrm{ml})$ and diethyl ether $(10 \mathrm{ml})$. The mono-arm complex was isolated as a orange powder (15 mg, 13\%); ${ }^{1} \mathrm{H}$ NMR (400 MHz, DMSO-d 6 ): $\delta_{\mathrm{H}} 9.18\left(\mathrm{~d}, 1 \mathrm{H},{ }^{3} \mathrm{~J}_{\mathrm{HH}}=8.0\right.$, phen $\left.2-\mathrm{H}\right), 8.76(\mathrm{~m}, 4 \mathrm{H}$, pyridyl $2-\mathrm{H}$, phen $4-\mathrm{H}, 9-\mathrm{H}$ and $10-\mathrm{H}), 8.70\left(\mathrm{~d}, 1 \mathrm{H},{ }^{3} J_{\mathrm{HH}}=8.0\right.$, pyridyl $\left.5-\mathrm{H}\right)$, $8.56\left(\mathrm{t}, 1 \mathrm{H},{ }^{3} J_{\mathrm{HH}}=8.0\right.$, phen $\left.3-\mathrm{H}\right), 8.04\left(\mathrm{t}, 1 \mathrm{H},{ }^{3} J_{\mathrm{HH}}=8.0\right.$, pyridyl 3-H), $7.98\left(\mathrm{t}, 1 \mathrm{H},{ }^{3} J_{\mathrm{HH}}=8.0\right.$, pyridyl $\left.4-\mathrm{H}\right), 7.70(\mathrm{~s}, 1 \mathrm{H}$, phen $7-\mathrm{H}$ ), 4.73 (br s, 3H, ethyl 1-H and pip $\mathrm{N}^{+}-\mathrm{H}$ ), 3.71 (br s, $2 \mathrm{H}$, ethyl 2-H), 3.31 (m, 4H, pip 1- $\mathrm{H}), 1.81$ (m, 4H, pip 2- $\mathrm{H})$, $1.58(\mathrm{~m}, 2 \mathrm{H}$, pip $3-\mathrm{H}) ;{ }^{31} \mathrm{P}$ NMR (400 MHz, DMSO-d 6 ): $\delta_{\mathrm{P}}$ -144.2 (sept, 2P, ${ }^{1} J_{\mathrm{P}-\mathrm{F}}=1756, \mathrm{PF}_{6}$ ); ESI-MS Calcd for $\mathrm{C}_{24} \mathrm{H}_{25} \mathrm{ClF}_{12} \mathrm{~N}_{4} \mathrm{OP}_{2} \mathrm{Pt}[\mathrm{M}]^{+}: 905.0$ a.m.u. Found $\left[\mathrm{M}-\mathrm{PF}_{6}\right]^{+}$: 759.0 a.m.u., $\left[\mathrm{M}-2 \mathrm{PF}_{6}\right]^{+}: 615.0$ a.m.u.; Anal. Calcd for $\mathrm{C}_{24} \mathrm{H}_{25} \mathrm{ClF}_{12} \mathrm{~N}_{4} \mathrm{OP}_{2}$ Pt: C 31.82, H 2.78, N 6.18; Found: C 31.24, H 2.97, N 5.32.

\section{X-ray crystallography}

Crystal data for 5. $\left[\mathrm{C}_{22} \mathrm{H}_{26} \mathrm{~N}_{4} \mathrm{PtS}\right](\mathrm{Cl})_{2} \cdot 2 \mathrm{MeOH}, M=708.60$, triclinic, $P \overline{1}$ (no. 2), $a=7.46100(15), b=13.0861(3), c=14.1346$ (3) А, $\alpha=85.6977(18), \beta=80.5574(17), \gamma=82.6405(18)^{\circ}, V=$ $1348.07(5) \AA^{3}, Z=2, \quad D_{\mathrm{c}}=1.746 \mathrm{~g} \mathrm{~cm} \mathrm{~cm}^{-3}, \mu(\mathrm{Cu}-\mathrm{K \alpha})=$ $12.511 \mathrm{~mm}^{-1}, T=173 \mathrm{~K}$, red needles, Oxford Diffraction Xcalibur PX Ultra diffractometer; 5329 independent measured reflections $\left(R_{\text {int }}=0.0306\right), F^{2}$ refinement, ${ }^{57-59} R_{1}(\mathrm{obs})=0.0295$, $\mathrm{w} R_{2}($ all $)=0.0748,4924$ independent observed absorptioncorrected reflections $\left[\left|F_{\mathrm{o}}\right|>4 \sigma\left(\left|F_{\mathrm{o}}\right|\right), 2 \theta_{\max }=145^{\circ}\right], 337$ parameters. CCDC 1023715.

Crystal data for 8. $\left[\mathrm{C}_{26} \mathrm{H}_{35} \mathrm{Cl}_{3} \mathrm{~N}_{7} \mathrm{OZn}_{2}\right]\left(\mathrm{ZnCl}_{4}\right)_{0.5} \cdot 0.5$ $\left(\mathrm{Me}_{2} \mathrm{CO}\right) \cdot 2 \mathrm{H}_{2} \mathrm{O}, M=867.36$, triclinic, $P \overline{1}$ (no. 2), $a=14.9174(4)$, $b=15.4884(5), c=18.5245(5) \AA, \alpha=69.026(3), \beta=81.075(2), \gamma=$ 63.677(3) ${ }^{\circ}, V=3582.0(2) \AA^{3}, Z=4$ (two independent molecules), $D_{\mathrm{c}}=1.608 \mathrm{~g} \mathrm{~cm}^{-3}, \mu(\mathrm{Cu}-\mathrm{K} \alpha)=5.773 \mathrm{~mm}^{-1}, T=173 \mathrm{~K}$, colourless needles, Oxford Diffraction Xcalibur PX Ultra diffractometer; 13810 independent measured reflections $\left(R_{\mathrm{int}}=\right.$ $0.0342), F^{2}$ refinement, ${ }^{57-59} R_{1}$ (obs) $=0.0378, \mathrm{w} R_{2}($ all $)=0.1087$, 11772 independent observed absorption-corrected reflections $\left[\left|F_{\mathrm{o}}\right|>4 \sigma\left(\left|F_{\mathrm{o}}\right|\right), 2 \theta_{\max }=145^{\circ}\right], 876$ parameters. CCDC 1023716.

Crystal data for 9. $\left[\mathrm{C}_{26} \mathrm{H}_{35} \mathrm{Cu}_{2} \mathrm{Cl}_{3} \mathrm{~N}_{7} \mathrm{O}\right](\mathrm{Cl}) \cdot 6.5 \mathrm{H}_{2} \mathrm{O}, \quad M=$ 847.59, monoclinic, $C 2 / c$ (no. 15), $a=38.832(4), b=14.0405(8)$, $c=13.7761(10) \AA$, $\beta=101.090(9)^{\circ}, V=7370.8(10) \AA^{3}, Z=8, D_{c}=$ $1.528 \mathrm{~g} \mathrm{~cm}^{-3}, \mu(\mathrm{Cu}-\mathrm{K} \alpha)=4.532 \mathrm{~mm}^{-1}, T=173 \mathrm{~K}$, blue platy needles, Oxford Diffraction Xcalibur PX Ultra diffractometer; 7202 independent measured reflections $\left(R_{\mathrm{int}}=0.0735\right)$, $F^{2}$ refinement, ${ }^{57-59} R_{1}(\mathrm{obs})=0.0779, \mathrm{w} R_{2}($ all $)=0.2702,4286$ independent observed absorption-corrected reflections $\left[\left|F_{\mathrm{o}}\right|>\right.$ $4 \sigma\left(\left|F_{\mathrm{o}}\right|\right), 2 \theta_{\max }=145^{\circ}$ ], 431 parameters. CCDC 1023717.

\section{Fluorescent intercalator displacement (FID) assay}

The FID assay was performed on a Varian Cary Eclipse spectrometer following a reported procedure. ${ }^{31,36}$ The 22AG strand
(5'-AGG-GTT-AGG-GTT-AGG-GTT-AGG-G-3') and 20AG strand (5'-GG-GAG-GGT-GGG-GAG-GGT-GGG-3') were used for the human telomeric and $c-M y c$ studies, respectively. For the duplex DNA studies, a 26 base pair self-complimentary strand (5'-CAA-TCG-GAT-CGA-ATT-CGA-TCC-GAT-TG-3') was used.

\section{UV-VIS titration procedure}

The UV-Vis spectra were recorded on a Perkin Elmer Lambda 25 spectrometer. In order to determine the binding constants of the selected complexes with $c-M y c$, Htelo and ct-DNA, the complexes $(50 \mu \mathrm{M})$ were titrated with concentrated solutions of DNA (c-Myc: $1.40 \mathrm{mM}$, Htelo: $2.50 \mathrm{mM}$ and ct-DNA: $4.56 \mathrm{mM}$ ) in $50 \mathrm{mM}$ Tris-HCl ( $\mathrm{pH} 7.4) / 100 \mathrm{mM} \mathrm{KCl}$ buffer. A $1 \mathrm{~cm}$ pathlength quartz cuvette was used to carry out the measurements. The binding constants were obtained by fitting the data to a reciprocal plot of $D / \Delta \varepsilon_{\text {ap }}$ versus $D$ using the following equation: $D / \Delta \varepsilon_{\text {ap }}=D / \Delta \varepsilon+1 /(\Delta \varepsilon \times K)$ where the concentration of DNA is expressed in terms of base pairs (determined by measuring the absorption at $260 \mathrm{~nm}$ and the appropriate extinction coefficients), the apparent molar extinction coefficient $\varepsilon_{\mathrm{a}}=A_{\text {observed }} /$ [complex], $\Delta \varepsilon_{\text {ap }}=\left[\varepsilon_{\mathrm{a}}-\varepsilon_{\mathrm{f}}\right]$ and $\Delta \varepsilon=\left[\varepsilon_{\mathrm{b}}-\varepsilon_{\mathrm{f}}\right] . \varepsilon_{\mathrm{b}}$ is the extinction coefficient of the DNA bound complex and $\varepsilon_{\mathrm{f}}$ is the extinction coefficient of the free complex.

\section{Cellular studies - general procedures}

The U2OS human osteosarcoma and GM05757 normal human fibroblast cell lines were obtained from the London Research Institute, Cancer Research UK. The cells were maintained in Dulbecco's Modified Eagle's Medium (DMEM-low glucose) media which was supplemented with $10 \%$ fetal bovine serum and $1 \%$ penicillin/streptomycin. All cells were grown at $310 \mathrm{~K}$ in a humidified atmosphere containing $5 \% \mathrm{CO}_{2}$.

\section{MTS cytotoxicity assays}

Cells $\left(5 \times 10^{4}\right.$ for U2OS and $1 \times 10^{4}$ for GM05757) were seeded in each well of a 96-well plate. After $24 \mathrm{~h}$ the cells were exposed to various concentrations of the test compound $(0-500 \mu \mathrm{M})$ for a further $24 \mathrm{~h}$ (total volume $100 \mu \mathrm{L}$ ). The test compounds were prepared as $10 \mathrm{mM}$ solutions in DMSO and diluted further using DMSO. The final concentration of DMSO in each well was $4 \%$. After the incubation period, $20 \mu \mathrm{L}$ of the MTS solution (made up of $2 \mathrm{mg} \mathrm{mL}^{-1}$ MTS reagent $+100 \mu \mathrm{L}$ of PMS $0.96 \mathrm{mg}$ $\mathrm{mL}^{-1}$ ) was added to each well. The mixture was incubated for a further $1.5 \mathrm{~h}$ at $37{ }^{\circ} \mathrm{C}$. After this time, the absorption at $490 \mathrm{~nm}$ was recorded and the $\mathrm{EC}_{50}$ values were determined using the Conventional Method ("Refinement in the Use and Data Analysis of the Promega CellTiter 96® AQueous NonRadioactive Cell Proliferation Assay" by A. Zarei and B. Markovic, Promega Corporation, 2000). $\mathrm{EC}_{50}$ values were calculated from the following equation: $\mathrm{Abs}_{\mathrm{EC}}=\left(\mathrm{Abs} \mathrm{EC}_{0}+\right.$ Abs $\left.\mathrm{EC}_{100}\right) / 2$; where $\mathrm{EC}_{0}$ is the mean absorption at $490 \mathrm{~nm}$ of the media only and $\mathrm{EC}_{100}$ is the mean absorption at $490 \mathrm{~nm}$ of the cells only (with $4 \%$ DMSO). Then the $x$-axis intercept of the dose-response curve at $\mathrm{Abs} \mathrm{EC}_{50}$ (determined by the above equation) was considered as the $\mathrm{EC}_{50}$ value for each test compound. The dose-response curve plot the concentration of test 
compound exposed to the cells ( $x$-axis) against absorption at $490 \mathrm{~nm}$ ( $y$-axis). Prior to plotting the curve the background absorption (due to the reaction of the test compound and MTS reagents) was subtracted from the absorption values obtained from the cells that had been incubated with the compounds.

\section{Cellular uptake protocol}

To measure the cellular uptake of the metal complexes, $c a$. 2 million U2OS cells were treated with $10 \mu \mathrm{M}$ of the corresponding compound at $37^{\circ} \mathrm{C}$ for $24 \mathrm{~h}$. Then the media was removed, the cells were washed with PBS solution $(\times 3)$, harvested from adherent cultures by trypsinization and centrifuged $(1000 \mathrm{~g}$ for $5 \mathrm{~min}$ ). The cellular pellet was suspended in an appropriate volume of PBS to obtain a homogeneous cell suspension. The suspension was divided in two. One part was used to analyse the metal content in the whole cell and the other was used for the cytoplasmic and nucleus analysis. The Thermo Scientific NE-PER Nuclear and Cytoplasmic Extraction Kit was used to extract the separate cytoplasmic and nuclear protein fractions. From each of the fraction aliquots were removed for protein determination using the Bradford Assay (carried according to the instructions of the manufacturer Sigma Aldrich, micro-well plate protocol). The remaining cell suspension was mineralized with $65 \% \mathrm{HNO}_{3}$ and then completely dried at $120{ }^{\circ} \mathrm{C}$. The solid extracts were re-dissolved in $2 \%$ $\mathrm{HNO}_{3}$ and analysed using ICP-MS. Cellular metal levels were expressed as ng metal/mg protein. Results are presented as the mean of 7 determinations for each data point \pm standard deviation obtained in three separate experiments. The fraction of the administered complexes that were taken up by the cells was calculated by dividing the amount of complex detected in the whole cell, cytoplasm and nucleus (i.e. the raw measurement in ng) by the total mass of metal corresponding to the concentration administered for each complex (10 $\mu \mathrm{M}$ converted to ng). The fractions were normalised so that all treated cells were accounted. The percentage of the administered complexes that were taken up by the cells was then determined by timing the normalised fractions by 100 .

\section{Acknowledgements}

The UK's Engineering and Physical Sciences Research Council (EPSRC) is thanked for studentships to V.S.S., K.S. and A.S., and a Leadership Fellowship to R.V. (grant number: $\mathrm{EP} / \mathrm{H} 005285 / 1)$. Johnson Matthey PLC is thanked for a generous loan of platinum.

\section{References}

1 P. L. T. Tran, A. De Cian, J. Gros, R. Moriyama and J.-L. Mergny, Top. Curr. Chem., 2013, 330, 243-274.

2 N. Maizels and L. T. Gray, PLoS Genet., 2013, 9, e1003468.

3 P. Murat and S. Balasubramanian, Curr. Opin. Genet. Dev., 2014, 25, 22-29.
4 S. Balasubramanian, L. H. Hurley and S. Neidle, Nat. Rev. Drug Discovery, 2011, 10, 261-275.

5 S. Balasubramanian and S. Neidle, Curr. Opin. Chem. Biol., 2009, 13, 345-353.

6 M. Duchler, J. Drug Targeting, 2012, 20, 389-400.

7 G. W. Collie and G. N. Parkinson, Chem. Soc. Rev., 2011, 40, 5867-5892.

8 D. Monchaud and M.-P. Teulade-Fichou, Org. Biomol. Chem., 2008, 6, 627-636.

9 A. Arola and R. Vilar, Curr. Top. Med. Chem., 2008, 8, 14051415.

10 S. Zhang, Y. Wu and W. Zhang, ChemMedChem, 2014, 9, 899-911.

11 S. N. Georgiades, N. H. Abd Karim, K. Suntharalingam and R. Vilar, Angew. Chem., Int. Ed., 2010, 49, 40204034.

12 N. H. Abd Karim, O. Mendoza, A. Shivalingam, A. J. Thompson, S. Ghosh, M. K. Kuimova and R. Vilar, RSC Adv., 2014, 4, 3355-3363.

13 J. E. Reed, S. Neidle and R. Vilar, Chem. Commun., 2007, 4366-4368.

14 K. Suntharalingam, A. Leczkowska, M. A. Furrer, Y. Wu, M. K. Kuimova, B. Therrien, A. J. P. White and R. Vilar, Chem. - Eur. J., 2012, 18, 16277-16282.

15 J. E. Reed, A. J. P. White, S. Neidle and R. Vilar, Dalton Trans., 2009, 2558-2568.

16 K. Suntharalingam, A. J. White and R. Vilar, Inorg. Chem., 2010, 49, 8371-8380.

17 K. Suntharalingam, A. J. P. White and R. Vilar, Inorg. Chem., 2009, 48, 9427-9435.

18 S. Ghosh, O. Mendoza, L. Cubo, F. Rosu, V. Gabelica, A. J. P. White and R. Vilar, Chem. - Eur. J., 2014, 20, 47724779.

19 H. Bertrand, D. Monchaud, A. De Cian, R. Guillot, J.-L. Mergny and M.-P. Teulade-Fichou, Org. Biomol. Chem., 2007, 5, 2555-2559.

20 H. Bertrand, S. Bombard, D. Monchaud, E. Talbot, A. Guedin, J.-L. Mergny, R. Grunert, P. J. Bednarski and M.-P. TeuladeFichou, Org. Biomol. Chem., 2009, 7, 2864-2871.

21 E. Largy, F. Hamon, F. Rosu, V. Gabelica, E. De Pauw, A. Guedin, J.-L. Mergny and M.-P. Teulade-Fichou, Chem. Eur. J., 2011, 17, 13274-13283.

22 A. Artese, L. Parrotta, S. Alcaro, F. Ortuso, G. Costa and C. Sissi, Open J. Med. Chem., 2013, 3, 41-49.

23 S. Bianco, C. Musetti, A. Waldeck, S. Sparapani, J. D. Seitz, A. P. Krapcho, M. Palumbo and C. Sissi, Dalton Trans., 2010, 39, 5833-5841.

24 K. J. Castor, J. Mancini, J. Fakhoury, N. Weill, R. Kieltyka, P. Englebienne, N. Avakyan, A. Mittermaier, C. Autexier, N. Moitessier and H. F. Sleiman, ChemMedChem, 2012, 7, 85-94.

25 A. F. Larsen, M. C. Nielsen and T. Ulven, Chem. - Eur. J., 2012, 18, 10892-10902.

26 C. Musetti, A. P. Krapcho, M. Palumbo and C. Sissi, PLoS One, 2013, 8, e58529.

27 S. F. Ralph, Curr. Top. Med. Chem., 2011, 11, 572-590. 
28 J. Wang, K. Lu, S. Xuan, Z. Toh, D. Zhang and F. Shao, Chem. Commun., 2013, 49, 4758-4760.

29 J.-T. Wang, X.-H. Zheng, Q. Xia, Z.-W. Mao, L.-N. Ji and K. Wang, Dalton Trans., 2010, 39, 7214-7216.

30 D. Monchaud, C. Allain, H. Bertrand, N. Smargiasso, F. Rosu, V. Gabelica, A. De Cian, J. L. Mergny and M. P. Teulade-Fichou, Biochimie, 2008, 90, 12071223.

31 D. Monchaud, C. Allain and M. P. Teulade-Fichou, Bioorg. Med. Chem. Lett., 2006, 16, 4842-4845.

32 C.-Q. Xia, X.-Y. Tan, S.-Y. Chen, Y. Yue and X.-Q. Yu, ARKIVOC, 2006, 68-76.

33 N. Lazarova, J. Babich, J. Valliant, P. Schaffer, S. James and J. Zubieta, Inorg. Chem., 2005, 44, 6763-6770.

34 J. J. Moore, J. J. Nash, P. E. Fanwick and D. R. McMillin, Inorg. Chem., 2002, 41, 6387-6396.

35 The $\mathrm{N}_{4} \mathrm{Cu}(2) \mathrm{Cl}(3)$ portion of the cation in the structure of 9 is highly disordered, so the details of the geometry should be treated with caution. See the ESI $\dagger$ for more details.

36 D. Monchaud, C. Allain, H. Bertrand, N. Smargiasso, F. Rosu, V. Gabelica, A. De Cian, J. L. Mergny and M. P. Teulade-Fichou, Biochimie, 2008, 90, 1207-1223.

37 R. Kieltyka, J. Fakhoury, N. Moitessier and H. F. Sleiman, Chem. - Eur. J., 2008, 14, 1145-1154.

38 V. Wing-Wah Yam, K. Kam-Wing Lo, K.-K. Cheung and R. Yuen-Chong Kong, J. Chem. Soc., Dalton Trans., 1997, 2067-2072.

39 S. Aoki and E. Kimura, J. Am. Chem. Soc., 2000, 122, 45424548.

40 C.-L. Do-Thanh, M. M. Rowland and M. D. Best, Tetrahedron, 2011, 67, 3803-3808.

41 B. Gruber, S. Stadlbauer, K. Woinaroschy and B. Konig, Org. Biomol. Chem., 2010, 8, 3704-3714.
42 F. Schmidt, S. Stadlbauer and B. Konig, Dalton Trans., 2010, 39, 7250-7261.

43 S. Aoki and E. Kimura, Chem. Rev., 2004, 104, 769-787.

44 I. M. A. del Mundo, M. A. Fountain and J. R. Morrow, Chem. Commun., 2011, 47, 8566-8568.

45 I. M. A. del Mundo, K. E. Siters, M. A. Fountain and J. R. Morrow, Inorg. Chem., 2012, 51, 5444-5457.

46 E. Kikuta, M. Murata, N. Katsube, T. Koike and E. Kimura, J. Am. Chem. Soc., 1999, 121, 5426-5436.

47 M. Shionoya, T. Ikeda, E. Kimura and M. Shiro, J. Am. Chem. Soc., 1994, 116, 3848-3859.

48 C. Rajput, R. Rutkaite, L. Swanson, I. Haq and J. A. Thomas, Chem. - Eur. J., 2006, 12, 4611-4619.

49 W. I. Sundquist and S. J. Lippard, Coord. Chem. Rev., 1990, 100, 293-322.

50 M. Read, R. J. Harrison, B. Romagnoli, F. A. Tanious, S. H. Gowan, A. P. Reszka, W. D. Wilson, L. R. Kelland and S. Neidle, Proc. Natl. Acad. Sci. U. S. A., 2001, 98, 4844-4849.

51 J. K. Barton and S. J. Lippard, Biochemistry, 1979, 18, 26612668.

52 J. C. Dewan, S. J. Lippard and W. R. Bauer, J. Am. Chem. Soc., 1980, 102, 858-860.

53 S. J. Lippard, Acc. Chem. Res., 1978, 11, 211-217.

54 C. Sanchez-Cano and M. J. Hannon, Dalton Trans., 2009, 10765-10773.

55 M. Huxley, C. Sanchez-Cano, M. J. Browning, C. NavarroRanninger, A. G. Quiroga, A. Rodger and M. J. Hannon, Dalton Trans., 2010, 39, 11353-11364.

56 R. J. Mureinik and M. Bidani, Inorg. Nucl. Chem. Lett., 1977, 13, 625-629.

57 G. M. Sheldrick, Acta Crystallogr., Sect. A: Found. Crystallogr., 2008, 64, 112-122.

58 SHELX-2013, http://shelx.uni-ac.gwdg.de/SHELX/index.php. 59 SHELXTL, Bruker AXS, Madison, WI. 